\title{
Inside out Capping Clusters: Matryoshka Series
}

\author{
Enos Masheija Rwantale Kiremire \\ Correspondence: Enos Masheija Rwantale Kiremire, Formerly, Professor of Chemistry at the University of Namibia, \\ Namibia; Serene Suites \& Hotel - Mutundwe, Wasswa Micheal Road, Mutundwe, P.O. Box 31654, Mutundwe, Rubaga, \\ Kampala, Uganda. E-mail: kiremire15@yahoo.com
}

Received: August 1, 2018 Accepted: November 5, 2018 Online Published: November 13, 2018

doi:10.5539/ijc.v10n4p38 URL: https://doi.org/10.5539/ijc.v10n4p38

\begin{abstract}
Matryoshka clusters have been analyzed and categorized using skeletal numbers for the first time. They have been found to portray a unique way of capping by having the nuclear elements occupying the outer layer and what were supposed to be the capping elements on the outside taking the place of the nucleus. Hence they belong to a new type of cluster series. The different types of capping clusters have been identified. Isomeric graphical structures of the clusters can be constructed in accordance with the connectivity rule of the series. It appears that the elements with large skeletal numbers have a tendency of going inside and forming an icosahedral shape. The $4 \mathrm{~N}$ series method is a useful hypothetical model for analyzing and categorizing clusters of the main group and transition metals.
\end{abstract}

Keywords: Matryoshka, inside-out capping, connectivity, clusters, cage clusters, icosahedral, Zintl ions, graph theory, 8 electron rule, 18 electron rule

\section{Introduction}

\subsection{Background}

Matryoshka clusters have attracted great attention of scientists since the beginning of this century (Moses,et al,2003;King\&Zhao,2006;Stegmaier\&Fässler,2011) due to their unique structure and bonding challenges. The extension of the research work on Zintl ions (Esenturk, et al, 2006) resulted in the discovery of Matryoshka clusters which were also described as superatoms requiring special bonding treatment(Huang, et al, 2014). The recent discovery of the simple $4 \mathrm{~N}$ series method which was found useful in categorizing clusters such as boranes, transition metal carbonyls and metalloboranes was successfully applied to the analysis and categorization of Zintl ions (Kiremire, 2016a). Further scrutiny of the $4 \mathrm{~N}$ series method, led to the discovery of skeletal numbers which have rendered the analysis of clusters much simpler (Kiremire, 2016b; 2017a,b; 2018a,b). The use of skeletal numbers has also been extended to the analysis and categorization of Zintl ion clusters (Kiremire, 2018c). This paper presents yet further application of the $4 \mathrm{~N}$ series method to analyze and categorize Matryoshka clusters for the first time.

\subsection{The Two Intrinsic Natural Layers of a Cluster}

The series equations used in this work were empirically developed by carefully analyzing a wide range of clusters especially the carbonyl clusters (Kiremire, 2016c). Among other aspects, they greatly assist in predicting the possible shapes of clusters and determine their cluster valence content. What has been found extremely interesting is the fact that the skeletal elements of a cluster are essentially divided into two groups, that is, those which are in the inner layer comprising of what has been referred to as a nucleus and those which reside outside the nucleus forming the outer layer. A capping formula was created for this purpose; $\mathrm{Kp}=\mathrm{C}^{\mathrm{y}} \mathrm{C}[\mathrm{Mx}], \mathrm{y}+\mathrm{x}=\mathrm{n}$ (the number of skeletal elements). In principle, the $\mathrm{x}$ in the capping formula in principle represents the number of skeletal elements in the nucleus and $\mathrm{y}$ represents the number of skeletal elements capping outside the nucleus (Kiremire, 2015). What is even exciting is the recent revelation is that when the vertices (nodes) are linked up in accordance to their valences, the resulting graph with the ligands and/or charges are distributed properly each of the nodes is found to obey the 8/18 electron rule accordingly(Kiremire,2018b). In this regard, the application of skeletal numbers is very useful. Several formulas for calculating cluster valence electrons have been developed (Kiremire, 2018c). The categorization of clusters into family series of $\mathrm{S}=4 \mathrm{n}+\mathrm{q}$ and clan series of $[\mathrm{Mx}]$ utilizing skeletal numbers is very extensive. This is a new approach of categorizing and analyzing clusters (Kiremire, 2018d). Clearly, this underpins the tremendous significance of the powerful insights by the two of the great American scientists who lived more than 130 years ago (Langmuir, 1921; Lewis, 1916). 


\section{Results and Discussion}

\subsection{The Nucleus Inside the Capping Elements}

The clusters $\mathrm{B}_{9} \mathrm{H}_{9}{ }^{2-}$ and $\mathrm{B}_{10} \mathrm{H}_{10}{ }^{2-}$ are members of the closo family of clusters and their shapes are described as tri-capped trigonal prism and bi-capped square anti prism (Housecroft and Sharpe, 2005). However, according to the $4 \mathrm{~N}$ series approach, these clusters simply belong to the closo family series, $S=4 n+2$ and not the capping series $S=4 n+q$ where $\mathrm{q} \leq 0$ (Kiremire, 2018a). Thus, the capping concept based upon the $4 \mathrm{~N}$ method and expressed in the symbol $\left\{\mathrm{Kp}=\mathrm{C}^{\mathrm{y}} \mathrm{C}[\mathrm{Mx}](\mathrm{y}+\mathrm{x}=\mathrm{n}, \mathrm{n}=\right.$ number of skeletal elements $), \mathrm{y} \rightarrow$ capping index, $\mathrm{x} \rightarrow$ nuclear index $\}$ is mathematically precise(Kiremire,2017a ). The application of the series method to categorize Zintl and Matryoshka clusters in this paper has revealed the existence of 3 broad types of capping clusters $(x \geq 1), y \geq 1)$. This concept is illustrated by the following examples.

The $4 \mathrm{~N}$ series method has been found to be able to analyze the golden clusters in the same way as other types of clusters (Kiremire, 2017d, 2018a-b). Let us consider the golden cluster $\mathrm{Au}_{9} \mathrm{~L}_{8}{ }^{3+}$ as an illustration. Its $\mathrm{K}$ value is given by $K=9[3.5]-8[1]+3[0.5]=25, n=9, K(n)=25(9) ; K p=C^{8} C[M 1]$. This means that the cluster has a nucleus of one skeletal element which is surrounded by 8 capping elements. This prediction has been found to be the case (Mingos, 1984; Konishi, 2014). The details of the analysis are given in Figure 1. Using skeletal numbers of $\mathrm{Au}(\mathrm{K}=3.5, \mathrm{v}=7)$ and valence of gold, and the capping symbol as a guide, a skeletal isomeric graph shown in Figure 1 is obtained.
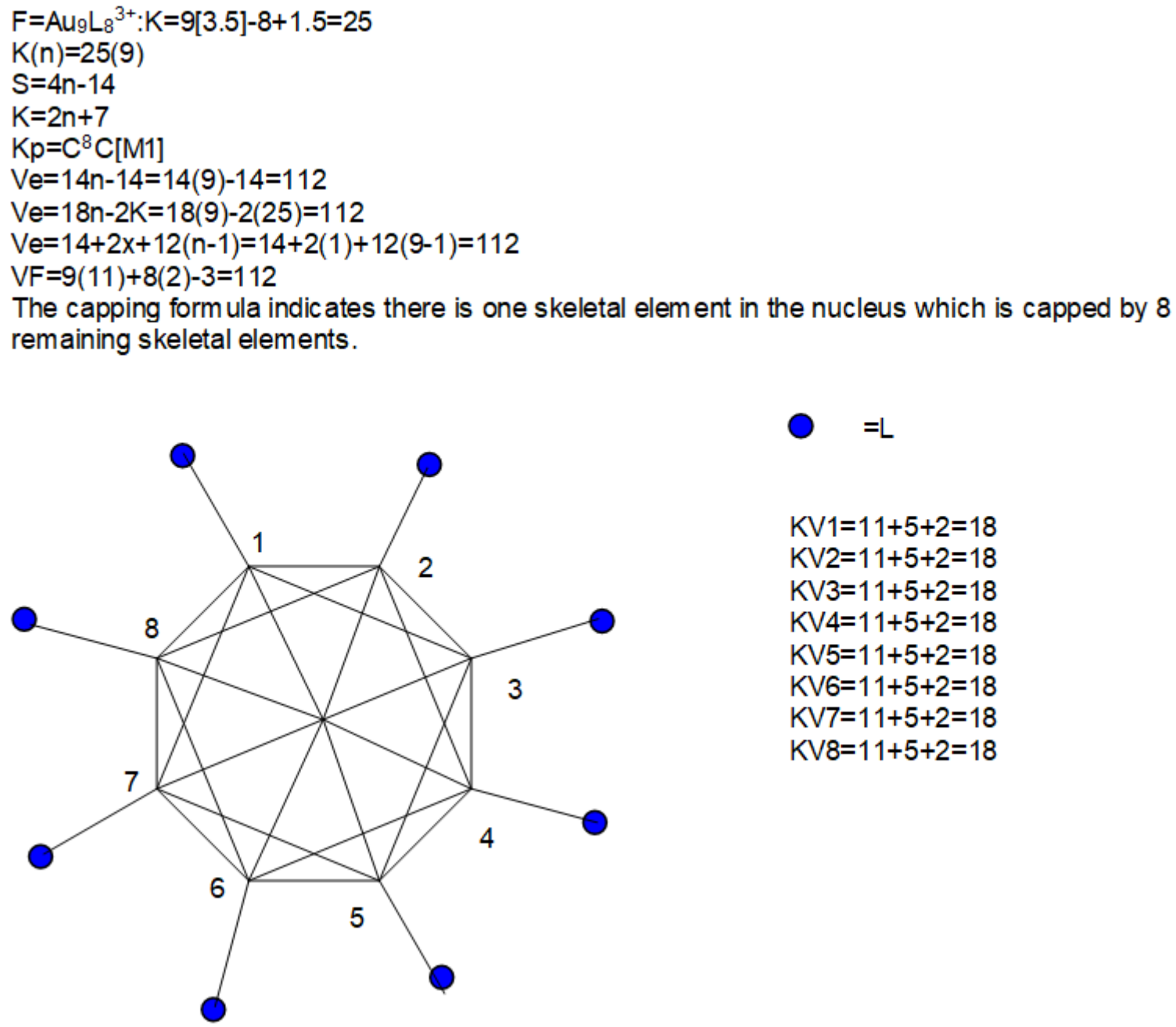

$K V 1=11+5+2=18$
$K V 2=11+5+2=18$
$K V 3=11+5+2=18$
$K V 4=11+5+2=18$
$K V 5=11+5+2=18$
$K V 6=11+5+2=18$
$K V 7=11+5+2=18$
$K V 8=11+5+2=18$

Figure 1. Isomeric graphical structure of $\mathrm{Au}_{9} \mathrm{~L}_{8}{ }^{3+}$

Each of the 8 vertices represents an Au skeletal element and the center contains the central skeletal element. The linkages in the graph add up to $8+8+8=24$. The central element [M1], $(n=1)$ belongs to the closo family, $S=4 n+2$, $\mathrm{K}=2 \mathrm{n}-1=2(1)-1=1$. Hence, the total linkages $=24+1$ (from nucleus $)=25$. Clusters have also been categorized into clans and families. In this case, the cluster as a whole belongs to the family of $\mathrm{S}=4 \mathrm{n}-14$ clusters but also of [M1] clan of clusters (Kiremire, 2018a). Also from series, the beginning of clusters was established at $n=0$ and the corresponding cluster valence electrons for initiating the capping process are given by $\mathrm{VE}_{0}=2 \mathrm{x}+2$ where $\mathrm{x}$ is the nuclear capping index 
which in this case $\mathrm{x}=1$. Hence, $\mathrm{VE}_{0}=2[1]+2=4$. These 4 electrons $(\mathrm{n}=0)$ can be used to derive the cluster valence electrons of the multiple skeletal elements or the cluster formula. In order to get the number of cluster valence electrons, we have to base them on the number of skeletal capping elements $=9$. This means, there will be 9 cappings of 12 electrons each being pilled upon the BASE of 4 electrons. This information can be formulated as $V E=V_{0}+12 n$ $=4+9[12]=112$. We can also start electron counting from the first element in which case, we get $V E=$ $[4+12]+12[9-1]=16+12[9-1]=16+12[8]=112$. We can generate the cluster formula in the same way as follows: $\mathrm{F}=\mathrm{G}_{0}+\mathrm{nF}_{0}=4 \mathrm{R}+9\left[\mathrm{Au}^{-}\right]=9 \mathrm{Au}+9 \mathrm{R}+4 \mathrm{R}=\mathrm{Au}_{9} \mathrm{R}_{13}=\mathrm{Au}_{9} \mathrm{~L}_{6.5}=\mathrm{Au}_{9} \mathrm{~L}_{8}{ }^{3+}$ (the $4 \mathrm{R}$ represent the four electrons). The $\left[\mathrm{Au}^{-}\right]$ fragment caries 12 electrons. Clearly the capping concept derived this way follows an arithmetic progression. A selected range of $\mathrm{K}(\mathrm{N})$ values for the [M1] clan clusters are given in Table 1 and some of known [M1] clusters are also given in Table2.

Table 1. Selected [M1] Clan Series

\begin{tabular}{l|r|r|r|r|r|r|r|r|r|r|r|r|r}
\hline & & & & & & & & & & & & & \\
\hline $\mathrm{K}$ & & & & & & & & & & & & & \\
\hline $\mathrm{N}$ & $\mathbf{0}$ & 1 & 2 & 3 & 4 & 5 & $\mathbf{6}$ & 7 & $\mathbf{8}$ & $\mathbf{9}$ & 10 & 11 & 12 \\
$\mathrm{~K}$ & $\mathbf{- 2}$ & 1 & 4 & 7 & 10 & 13 & $\mathbf{1 6}$ & 19 & $\mathbf{2 2}$ & $\mathbf{2 5}$ & 28 & 31 & 34 \\
\hline $\mathrm{VE}$ & $\mathbf{4}$ & 16 & 28 & 40 & 52 & 64 & $\mathbf{7 6}$ & 88 & $\mathbf{1 0 0}$ & $\mathbf{1 1 2}$ & 124 & 136 \\
\hline
\end{tabular}

Table 2. Selected [M1] clan clusters and the derivation of their cluster valence electrons using a capping formula

\begin{tabular}{|c|c|c|c|c|c|c|c|c|c|c|c|}
\hline CLUSTER & $\mathrm{K}$ & $\mathrm{N}$ & $\mathrm{K}(\mathrm{N})$ & $\begin{array}{l}\text { SERIE } \\
\mathrm{S}\end{array}$ & K & $\mathrm{Kp}$ & $\begin{array}{l}\text { CLAN[M } \\
\mathrm{x}]\end{array}$ & $\begin{array}{l}\mathrm{VE}_{0}=2 \mathrm{x} \\
+2\end{array}$ & $\mathrm{VE}_{1}=\mathrm{VE}_{0}+12$ & $\mathrm{VE}_{\mathrm{n}}=\mathrm{VE}_{1}+12(\mathrm{n}-1)$ & $\mathrm{VF}$ \\
\hline $\mathrm{Au}_{6} \mathrm{~L}_{6}{ }^{2+}$ & 16 & 6 & $16(6)$ & $4 n-8$ & $2 n+4$ & $\mathrm{C}^{5} \mathrm{C}[\mathrm{M} 1]$ & [M1] & 4 & 16 & 76 & 76 \\
\hline $\mathrm{Au}_{6} \mathrm{~L}_{4} \mathrm{Cl}_{2}$ & 16 & 6 & $16(6)$ & $4 n-8$ & $2 n+4$ & $\mathrm{C}^{5} \mathrm{C}[\mathrm{M} 1]$ & [M1] & 4 & 16 & 76 & 76 \\
\hline $\mathrm{Au}_{8} \mathrm{~L}_{7}^{2+}$ & 22 & 8 & $22(8)$ & $4 n-12$ & $2 n+6$ & $\mathrm{C}^{7} \mathrm{C}[\mathrm{M} 1]$ & [M1] & 4 & 16 & 100 & 100 \\
\hline $\mathrm{Au}_{8} \mathrm{~L}_{6} \mathrm{I}^{+}$ & 22 & 8 & $22(8)$ & $4 n-12$ & $2 n+6$ & $\mathrm{C}^{7} \mathrm{C}[\mathrm{M} 1]$ & [M1] & 4 & 16 & 100 & 100 \\
\hline $\mathrm{Au}_{9} \mathrm{~L}_{8}^{3+}$ & 22 & 8 & $22(8)$ & $4 n-14$ & $2 n+7$ & $\mathrm{C}^{8} \mathrm{C}[\mathrm{M} 1]$ & [M1] & 4 & 16 & 112 & 112 \\
\hline $\operatorname{Pt}(\mathrm{AuL})_{8}^{2+}$ & 25 & 9 & $25(9)$ & $4 n-14$ & $2 n+7$ & $\mathrm{C}^{8} \mathrm{C}[\mathrm{M} 1]$ & [M1] & 4 & 16 & 112 & 112 \\
\hline $\mathrm{Pd}(\mathrm{AuL})_{8}{ }^{2+}$ & 25 & 9 & $25(9)$ & $4 n-14$ & $2 n+7$ & $\mathrm{C}^{8} \mathrm{C}[\mathrm{M} 1]$ & [M1] & 4 & 16 & 112 & 112 \\
\hline $\mathrm{Au}_{10} \mathrm{Cl}_{3} \mathrm{~L}_{6}^{+}$ & 28 & 10 & $28(10)$ & $4 n-16$ & $2 n+8$ & $\mathrm{C}^{9} \mathrm{C}[\mathrm{M} 1]$ & [M1] & 4 & 16 & 124 & 124 \\
\hline $\mathrm{Au}_{11} \mathrm{~L}_{10}{ }^{5+}$ & 31 & 10 & $31(11)$ & $4 n-18$ & $2 n+9$ & $\mathrm{C}^{10} \mathrm{C}[\mathrm{M} 1]$ & [M1] & 4 & 16 & 136 & 136 \\
\hline
\end{tabular}

As can be seen from the Table1 when $\mathrm{n}=0$, the arithmetic capping progression starts with $\mathrm{VE}_{0}=4$ and when the series start at $\mathrm{n}=1$, the arithmetic capping progression starts with $\mathrm{VE}_{1}=4+12=16$. Hence, $\mathrm{VE}_{\mathrm{n}}=16+12(\mathrm{n}-1)$. The clusters whose cluster valence obeys this equation are the one referred to as TORROIDAL (Mingos, 1984). On the other hand, the cluster $\mathrm{Au}_{9} \mathrm{~L}_{8}{ }^{+}$; has $\mathrm{K}=9[3.5]-8[1]+1[0.5]=24, \mathrm{n}=9, \mathrm{~K}(\mathrm{n})=24(9), \mathrm{S}=4 \mathrm{n}-12, \mathrm{~K}=2 \mathrm{n}+6$ and $\mathrm{Kp}=\mathrm{C}^{7} \mathrm{C}[\mathrm{M} 2]$. This means that we have a cluster which belongs to the [M2] clan but of the family of cluster series $S=4 n-12$. Accordingly, the [M2] clan series commence at $\mathrm{n}=0$ with $\mathrm{VE}_{0}=2 \mathrm{x}+2=2(2)+2=6$. Therefore $\mathrm{VE}_{1}=6+12=18$ and $\mathrm{VE}=18+12(9-1)=114$ or $\mathrm{VE}=6+12(9)=114$. The [M2] clusters were referred to as SPHERICAL (Mingos, 1984). According to the series approach, these cluster can be viewed as having a nucleus of 2 skeletal elements bound by essentially a triple bond since [M2] belongs to the closo family, $S=4 n+2$ and $K=2 n-1=2(2)-1=3$. All in all, the golden clusters, obey the $14 N / 4 N$ series along with their skeletal numbers and valences. The isomeric graphical sketch of $\mathrm{Au}_{9} \mathrm{~L}_{8}{ }^{+}$is given in Figure 2 and selected $\mathrm{K}(\mathrm{N})$ series of clan [M2] are given in Table 3 as well as some of the known clan members are also provided in Table 4. As some [M1] clusters with visible single skeletal nuclear skeletal elements are clearly identified and known, it is hoped that the cluster nuclei with 2 clearly identified skeletal elements will be well defined. 


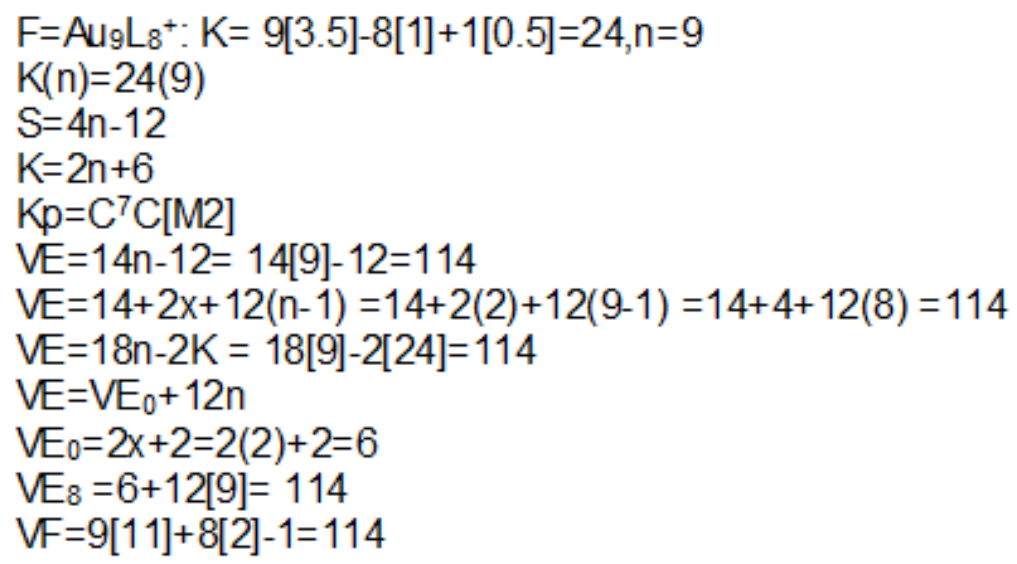

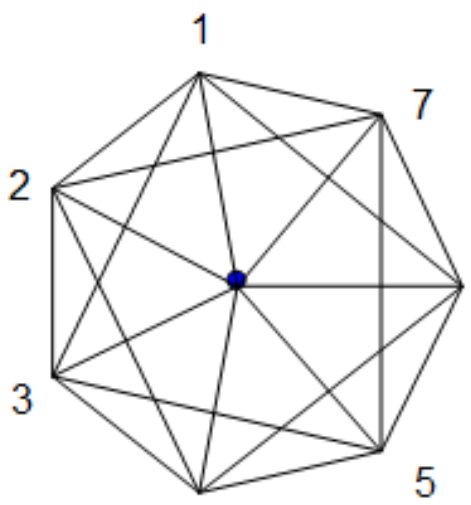

6

4

$\mathrm{EC} 1=1[11]+5[1]+1[2]=18$

$\mathrm{EC} 2=\mathrm{EC} 1=18$

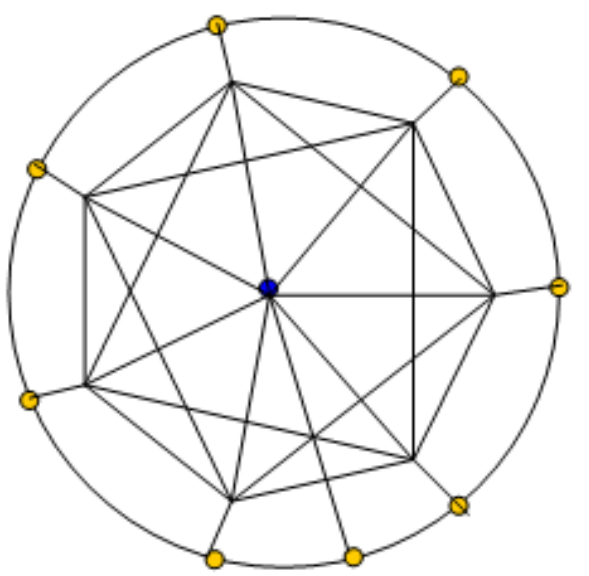

$\mathrm{EC} 3=\mathrm{EC} 1=18$

$\mathrm{EC} 4=\mathrm{EC} 1=18$

$\mathrm{EC} 5=\mathrm{EC} 1=18$

$\mathrm{EC} 6=\mathrm{EC} 1=18$

$\mathrm{EC} 7=\mathrm{EC} 1=18$

Figure 2. Isomeric graphical structure of $\mathrm{Au}_{9} \mathrm{~L}_{8}{ }^{3+}$

Table 3. Selected [M2] Clan Series

\begin{tabular}{l|r|r|r|r|r|r|r|r|r|r|r|r|r|r|r}
\hline $\mathrm{K}$ & & & & & & & & & & & & & & & \\
\hline $\mathrm{N}$ & $\mathbf{0}$ & $\mathbf{1}$ & $\mathbf{2}$ & 3 & $\mathbf{4}$ & 5 & 6 & $\mathbf{7}$ & $\mathbf{8}$ & $\mathbf{9}$ & 10 & $\mathbf{1 1}$ & 12 & $\mathbf{1 3}$ & 14 \\
\hline $\mathrm{K}$ & $\mathbf{- 3}$ & $\mathbf{0}$ & $\mathbf{3}$ & $\mathbf{6}$ & $\mathbf{9}$ & 12 & 15 & $\mathbf{1 8}$ & $\mathbf{2 1}$ & $\mathbf{2 4}$ & 27 & $\mathbf{3 0}$ & 33 & $\mathbf{3 6}$ & 39 \\
\hline $\mathrm{VE}$ & $\mathbf{6}$ & $\mathbf{1 8}$ & $\mathbf{3 0}$ & 42 & $\mathbf{5 4}$ & 66 & 78 & $\mathbf{9 0}$ & $\mathbf{1 0 2}$ & $\mathbf{1 1 4}$ & 126 & $\mathbf{1 3 8}$ & 150 & $\mathbf{1 6 2}$ & 174 \\
\hline
\end{tabular}


Table 4. Selected [M2] clan clusters and the derivation of their cluster valence electrons using a capping formula

\begin{tabular}{|c|c|c|c|c|c|c|c|c|c|c|c|}
\hline & & & & & & & $\begin{array}{l}\text { CLAN[ } \\
\mathrm{Mx}]\end{array}$ & $\begin{array}{l}V E_{0}=2 \mathrm{x} \\
+2\end{array}$ & $\begin{array}{l}\mathrm{VE}_{1}=\mathrm{VE}_{0}+1 \\
2\end{array}$ & $\begin{array}{l}\mathrm{VE}_{\mathrm{n}}=\mathrm{VE}_{1} \\
+12(\mathrm{n}-1)\end{array}$ & VF \\
\hline $\mathrm{Au}_{4} \mathrm{~L}_{4} \mathrm{I}_{2}$ & 9 & 4 & $9(4)$ & $4 n-2$ & $2 n+1$ & $\mathrm{C}^{2} \mathrm{C}[\mathrm{M} 2]$ & [M2] & 6 & 18 & 54 & 54 \\
\hline $\mathrm{Au}_{7} \mathrm{~L}_{7}^{+}$ & 18 & 7 & $18(7)$ & $4 n-8$ & $2 n+4$ & $\mathrm{C}^{5} \mathrm{C}[\mathrm{M} 2]$ & [M2] & 6 & 18 & 90 & 90 \\
\hline $\mathrm{Au}_{8} \mathrm{~L}_{8}{ }^{2+}$ & 21 & 8 & $21(8)$ & $4 n-10$ & $2 n+5$ & $\mathrm{C}^{6} \mathrm{C}[\mathrm{M} 2]$ & [M2] & 6 & 18 & 102 & 102 \\
\hline $\mathrm{Au}_{9} \mathrm{~L}_{8}^{+}$ & 24 & 8 & $24(8)$ & $4 n-12$ & $2 n+6$ & $\mathrm{C}^{7} \mathrm{C}[\mathrm{M} 2]$ & [M2] & 6 & 18 & 114 & 114 \\
\hline $\mathrm{Pt}(\mathrm{CO})(\mathrm{AuL})_{8}^{2}$ & 24 & 9 & $24(9)$ & $4 n-12$ & $2 n+6$ & $\mathrm{C}^{\top} \mathrm{C}[\mathrm{M} 2]$ & [M2] & 6 & 18 & 114 & 114 \\
\hline$\underset{2+}{\operatorname{Pd}(\mathrm{CO})(\mathrm{AuL})_{8}}$ & 24 & 9 & $24(9)$ & $4 n-12$ & $2 n+6$ & $\mathrm{C}^{7} \mathrm{C}[\mathrm{M} 2]$ & [M2] & 6 & 18 & 114 & 114 \\
\hline $\mathrm{Au}_{10} \mathrm{~L}_{8} \mathrm{Cl}^{+}$ & 27 & 10 & $27(10)$ & $4 n-14$ & $2 n+7$ & $\mathrm{C}^{8} \mathrm{C}[\mathrm{M} 2]$ & [M2] & 6 & 18 & 126 & 126 \\
\hline $\mathrm{Au}_{11} \mathrm{I}_{3} \mathrm{~L}_{7}$ & 30 & 11 & $30(11)$ & $4 n-16$ & $2 n+8$ & $\mathrm{C}^{9} \mathrm{C}[\mathrm{M} 2]$ & [M2] & 6 & 18 & 138 & 138 \\
\hline $\mathrm{Au}_{11} \mathrm{~L}_{10}{ }^{3+}$ & 30 & 11 & $30(11)$ & $4 n-16$ & $2 n+8$ & $\mathrm{C}^{9} \mathrm{C}[\mathrm{M} 2]$ & [M2] & 6 & 18 & 138 & 138 \\
\hline $\mathrm{Au}_{13} \mathrm{Cl}_{3} \mathrm{~L}_{10}{ }^{3+}$ & 36 & 13 & $36(13)$ & $4 n-20$ & $2 n+10$ & $\mathrm{C}^{11} \mathrm{C}[\mathrm{M} 2]$ & [M2] & 6 & 18 & 162 & 162 \\
\hline
\end{tabular}

The [M6] Clan Series

It is interesting to know that some clusters with well- marked octahedral nuclei have been identified. These belong to the [M6] clan clusters. They include, $\mathrm{Pt}_{6} \mathrm{Ni}_{38}(\mathrm{CO})_{48}{ }^{6-}$ (Rossi and Zanello,2011) which was found to have an octahedral nucleus of platinum skeletal elements. The series method gives the $\mathrm{K}=6[4]+38[4]-48[1]-6[0.5]=125, \mathrm{n}=6+38=44$ and hence $K(n)=125(44) ; S=4 n-74, K=2 n+37, K p=C^{38} C[M 6]$. This means the cluster has an octahedral nucleus of six skeletal elements surrounded by 38 capping skeletal elements as reported by Rossi and Zanello. If we take the genesis of the cluster as $\mathrm{n}=0$, then according to the series approach $\mathrm{VE}_{0}=2 \mathrm{x}+2(\mathrm{x}=6)=14$. Thus, the cluster of 44 skeletal elements begins capping on a BASE of 14 electrons. Since according to the series method, each capping fragment is a conveyor of 12 electrons, we can actually work out the cluster valence electrons when all the skeletal elements have been capped. Thus, $\mathrm{VE}_{44}=14+12[44]=542$. This can be compared with the cluster valence electrons $\mathrm{VF}$ calculated from the formula $\mathrm{VF}=6[10]+38[10]+48[2]+6=542$. We can also use the information to derive the cluster formula as follows:

$7 \mathrm{CO}+6[\mathrm{Pt}(\mathrm{CO})]+38[\mathrm{Ni}(\mathrm{CO})]=\mathrm{Pt}_{6} \mathrm{Ni}_{38}(\mathrm{CO})_{51}=\mathrm{Pt}_{6} \mathrm{Ni}_{38}(\mathrm{CO})_{48}{ }^{6-}$. A selected sample of clusters analyzed by the series method as having octahedral nuclei are shown in Table 5 and a sample of [M6] clan $\mathrm{K}(\mathrm{N})$ series are also given in Table 6 including the genesis cluster valence electrons.

Table 5. Selected [M6] Clan Member Clusters

\begin{tabular}{|c|c|c|c|c|c|c|c|c|c|}
\hline CLUSTER & K & $\mathrm{N}$ & $\mathrm{K}(\mathrm{N})$ & $\begin{array}{l}\text { SERIES } \\
4 \mathrm{n}+\mathrm{q}\end{array}$ & $\begin{array}{l}\mathrm{K}=2 \mathrm{n}- \\
1 / 2 \mathrm{q}\end{array}$ & $\begin{array}{l}\mathrm{Kp}=\mathrm{C}^{\mathrm{y}} \mathrm{C}[\mathrm{Mx}], \\
\mathrm{y}+\mathrm{x}=\mathrm{n}\end{array}$ & $V E=14 n+q$ & $V E=14+12 n$ & VF \\
\hline $\mathrm{Os}_{6}(\mathrm{CO})_{18}{ }^{2-}$ & 11 & 6 & $11(6)$ & $4 n+2$ & $2 n-1$ & $\mathrm{C}^{0} \mathrm{C}[\mathrm{M} 6]$ & $14 n+2=86$ & $14+12[6]=86$ & 86 \\
\hline $\mathrm{Os}_{7}(\mathrm{CO})_{21}$ & 14 & 7 & $14(7)$ & $4 n+0$ & $2 \mathrm{n}+0$ & $\mathrm{C}^{\mathrm{I}} \mathrm{C}[\mathrm{M} 6]$ & $14 n+0=98$ & $14+12[7]=98$ & 98 \\
\hline $\mathrm{Os}_{8}(\mathrm{CO})_{22}{ }^{2-}$ & 17 & 8 & $17(8)$ & $4 n-2$ & $2 n+1$ & $\mathrm{C}^{2} \mathrm{C}[\mathrm{M} 6]$ & $14 n-2=110$ & $14+12[8]=110$ & 110 \\
\hline $\mathrm{Os}_{9}(\mathrm{CO})_{24}{ }^{2-}$ & 20 & 9 & $20(9)$ & $4 n-4$ & $2 n+2$ & $\mathrm{C}^{3} \mathrm{C}[\mathrm{M} 6]$ & $14 n-4=122$ & $14+12[9]=122$ & 122 \\
\hline $\mathrm{Os}_{10}(\mathrm{CO})_{26}{ }^{2-}$ & 23 & 10 & $23(10)$ & $4 n-6$ & $2 n+3$ & $\mathrm{C}^{4} \mathrm{C}[\mathrm{M} 6]$ & $14 n-6=134$ & $14+12[10]=134$ & 134 \\
\hline $\mathrm{Rh}_{13}(\mathrm{CO})_{24} \mathrm{H}_{2}{ }^{3-}$ & 32 & 13 & $32(13)$ & $4 n-12$ & $2 n+6$ & $\mathrm{C}^{\prime} \mathrm{C}[\mathrm{M} 6]$ & $14 n-12=170$ & $14+12[13]=170$ & 170 \\
\hline $\operatorname{Ir}_{14}(\mathrm{CO})_{27}^{2-}$ & 35 & 14 & $35(14)$ & $4 n-14$ & $2 n+7$ & $\mathrm{C}^{8} \mathrm{C}[\mathrm{M} 6]$ & $14 n-14=182$ & $14+12[14]=182$ & 182 \\
\hline $\mathrm{Pt}_{24}(\mathrm{CO})_{30}{ }^{2-}$ & 65 & 24 & $65(24)$ & $4 n-34$ & $2 n+17$ & $\mathrm{C}^{18} \mathrm{C}[\mathrm{M} 6]$ & $14 n-34=302$ & $14+12[24]=302$ & 302 \\
\hline $\mathrm{Pt}_{26}(\mathrm{CO})_{32}{ }^{2-}$ & 71 & 26 & $71(26)$ & $4 n-38$ & $2 n+19$ & $\mathrm{C}^{20} \mathrm{C}[\mathrm{M} 6]$ & $14 n-38=326$ & $14+12[26]=326$ & 326 \\
\hline $\mathrm{Pd}_{29}(\mathrm{CO})_{28} \mathrm{~L}_{7}^{2=}$ & 80 & 29 & $80(29)$ & $4 n-44$ & $2 n+22$ & $\mathrm{C}^{23} \mathrm{C}[\mathrm{M} 6]$ & $14 n-44=362$ & $14+12[29]=362$ & 362 \\
\hline $\mathrm{Pd}_{33} \mathrm{Ni}_{9}(\mathrm{CO})_{41} \mathrm{~L}_{6}{ }^{4-}$ & 119 & 42 & $119(42)$ & $4 n-70$ & $2 n+35$ & $\mathrm{C}^{36} \mathrm{C}[\mathrm{M} 6]$ & $14 n-70=518$ & $14+12[42]=518$ & 518 \\
\hline $\mathrm{Pt}_{6} \mathrm{Ni}_{38}(\mathrm{CO})_{48}{ }^{6-}$ & 125 & 44 & $125(44)$ & $4 n-74$ & $2 n+37$ & $\mathrm{C}^{38} \mathrm{C}[\mathrm{M} 6]$ & $14 n-74=542$ & $14+12[44]=542$ & 542 \\
\hline
\end{tabular}

Table 6. Selected [M6] Clan Series

\begin{tabular}{|c|c|c|c|c|c|c|c|c|c|c|c|c|c|c|c|}
\hline K & $2 n-1$ & $2 n+0$ & $2 n+1$ & $2 n+2$ & $2 n+3$ & $2 n+4$ & $2 n+5$ & $2 n+6$ & $2 n+7$ & $2 n+8$ & $2 n+9$ & $2 n+10$ & $2 n+11$ & $2 n+12$ & $2 n+13$ \\
\hline $\mathrm{N}$ & 6 & 7 & 8 & 9 & 10 & 11 & 12 & 13 & 14 & 15 & 16 & 17 & 18 & 19 & 20 \\
\hline K & 11 & 14 & 17 & 20 & 23 & 26 & 29 & 32 & 35 & 38 & 41 & 44 & 47 & 50 & 53 \\
\hline VE & 86 & 98 & 110 & 122 & 134 & 146 & 158 & 170 & 182 & 194 & 206 & 218 & 230 & 242 & 254 \\
\hline $\mathrm{K}$ & $2 n+14$ & $2 n+15$ & $2 n+16$ & $2 n+17$ & $2 n+18$ & $2 n+19$ & $2 n+20$ & $2 n+21$ & $2 n+22$ & $2 n+23$ & $2 n+24$ & $2 n+25$ & $2 n+26$ & $2 n+27$ & $2 n+28$ \\
\hline $\mathrm{N}$ & 21 & 22 & 23 & 24 & 25 & 26 & 27 & 28 & 29 & 30 & 31 & 32 & 33 & 34 & 35 \\
\hline $\mathrm{K}$ & 56 & 59 & 62 & 65 & 68 & 71 & 74 & 77 & 80 & 83 & 86 & 89 & 92 & 95 & 98 \\
\hline VE & 266 & 278 & 290 & 302 & 314 & 326 & 338 & 350 & 362 & 374 & 386 & 398 & 410 & 422 & 434 \\
\hline $\mathrm{K}$ & $2 n-1$ & $2 n-2$ & $2 n-3$ & $2 n-4$ & $2 n-5$ & $2 n-6$ & $2 n-7$ & $2 n-8$ & $2 n-9$ & $2 n-10$ & $2 n-11$ & $2 n-12$ & $2 n-13$ & $2 n-14$ & $2 n-15$ \\
\hline $\mathrm{N}$ & $\mathbf{0}$ & $\mathrm{s}$ & 4 & 3 & 2 & 1 & 0 & -1 & -2 & -5 & -4 & -5 & -6 & -7 & -8 \\
\hline $\mathrm{K}$ & 11 & 8 & 5 & 2 & -1 & -4 & -7 & -10 & -13 & -16 & -19 & -22 & -25 & -28 & -31 \\
\hline $\mathrm{VE}$ & 86 & 74 & 62 & 50 & 38 & 26 & 14 & 2 & -10 & -22 & -34 & -46 & -58 & -70 & -82 \\
\hline
\end{tabular}


The highlighted numbers denote some of important $\mathrm{K}(\mathrm{N})$ values or cluster valence electrons of known clusters. Another example of a cluster with an octahedral nucleus is $\mathrm{Pd}_{23}(\mathrm{CO})_{20} \mathrm{~L}_{10}\left(\mathrm{~L}=\mathrm{PEt}_{3}\right)($ Mednilov \& Dahl, 2010). The $\mathrm{K}$ value of the cluster is given by $K=23[4]-20[1]-10[1]=62 ; K(n)=62(23), S=4 n-32, K=2 n+16, K p=C^{17} C[M 6]$. This symbol means that the cluster has an octahedral nucleus comprising of six of the skeletal elements and surrounded by 17 capping skeletal elements. A hypothetical isomeric graphical structure is given in Figure 3A.

$$
\begin{aligned}
& \mathrm{F}=\mathrm{Pd}_{23}(\mathrm{CO})_{20} \mathrm{~L}_{10} \\
& \mathrm{~K}=62 \\
& \mathrm{Kp}=\mathrm{C}{ }^{17} \mathrm{C}[\mathrm{M} 6] \\
& \\
& \mathrm{K} 11=4-2.5=1.5 \\
& \mathrm{~K} 12=4--3=1 \\
& \mathrm{~K} 13=4-3.5=0.5 \\
& \mathrm{~K} 21=4-1.5=2.5 \\
& \mathrm{~K} 22=4-2.5=1.5 \\
& \mathrm{~K} 23=4-3=1 \\
& \mathrm{~K} 24=4-3.5=0.5 \\
& \mathrm{~K} 31=4-1.5=2.5 \\
& \mathrm{~K} 32=4-3=1 \\
& \mathrm{~K} 33=4-3=1 \\
& \mathrm{~K} 34=4-3=1 \\
& \mathrm{KT}=14
\end{aligned}
$$

3

$\mathrm{K} 41=4-1.5=2.5$

$\mathrm{K} 42=4-3=1$

$\mathrm{K} 43=4-3=1$

$\mathrm{K} 44=4-3.5=0.5$

$\mathrm{K} 51=4-1.5=2.5$

$\mathrm{K} 52=4-3=1$

$\mathrm{K} 53=4-3=1$

$\mathrm{K} 54=4-3=1$

$4 \mathrm{~K} 61=4-1.5=2.5$

$\mathrm{K} 62=4-2.5=1.5$

$\mathrm{K} 63=4-3=1$

$\mathrm{K} 64=4-3.5=0.5$

$K T=16$.

\section{5}

Figure 3A. Possible ligand distribution in isomeric graphical structure of $\operatorname{Pd} 23(\mathrm{CO})_{20} \mathrm{~L}_{10}$

Thus, unlike other methods of analyzing clusters, the identification of the type of a cluster nucleus is one of the characteristics of the $4 \mathrm{~N}$ method. In addition, the isomeric graphical sketch when correctly constructed, every vertex obeys 18/8 electron rule accordingly. The method has satisfactorily explained the structures of a good number of golden clusters (Kiremire, 2016d, 2017d,2018b). Let us take the case of $\mathrm{Au}_{13} \mathrm{Cl}_{2} \mathrm{~L}_{10}{ }^{3+}, \mathrm{L}=\mathrm{PR}_{3}$ (Fehlner \& Halet, 2007). Its cluster valence electrons is given by $\mathrm{VE}=18+12 \mathrm{n} .=18+12(12)=162$. It is explained that the figure of [18] represents the central skeletal element of the cluster (Fehlner \& Halet, 2007). This result is also explained well using the series method with the aid of the skeletal numbers. Thus, the $K$ value of the cluster is given by $K=13[3.5]-2[0.5]-10[1]+3[0.5]=36$, $K(n)=36(13), S=4 n-20, K=2 n+10, K p=C^{11} C[M 2] . \quad$ This means that, ideally, the cluster has two skeletal elements at the nucleus,[M2] bound by a triple bond as in the case of $N_{2}$ and the fragment [M2] belongs to the closo family $S=4 n+2$, $\mathrm{K}=2 \mathrm{n}-1=2(2)-1=3$. There are several equations developed from the study of clusters using the $4 \mathrm{~N}$ series method. These are illustrated as $\mathrm{VE}=14 \mathrm{n}-20=14[13]-20=162 ; \mathrm{VE}=18 \mathrm{n}-2 \mathrm{~K}=18[13]-2[36]=162$;

$\mathrm{VE}=14+2 \mathrm{x}+12(\mathrm{n}-1)=14+2[2]+12[13-1]=14+4+12[12]=162 ; \mathrm{VEn}=\mathrm{VE}_{0}+12 \mathrm{n}$ or $\mathrm{VE}_{\mathrm{n}}=\mathrm{VE}_{1}+12(\mathrm{n}-1) ; \mathrm{VE}_{0}=2 \mathrm{x}+2$ $=2[2]+2=6$; hence, $\mathrm{VE}_{13}=6+12[13]=162$ or $\mathrm{VE}_{13}=\mathrm{VE}_{1}+12(\mathrm{n}-1)=[6+12]+12[13-1]=$

$18+12[13-1]=18+12[12]=18+144=162$. As we can see the capping process follows a well-defined arithmetic progression from the BASE cluster valence electrons $\mathrm{VE}_{0}=6$ (when $\mathrm{n}=0$ ). The isomeric graphical structure of $\mathrm{Au}_{13} \mathrm{Cl}_{2} \mathrm{~L}_{10}{ }^{3+}$ is shown in Figure 3B. 


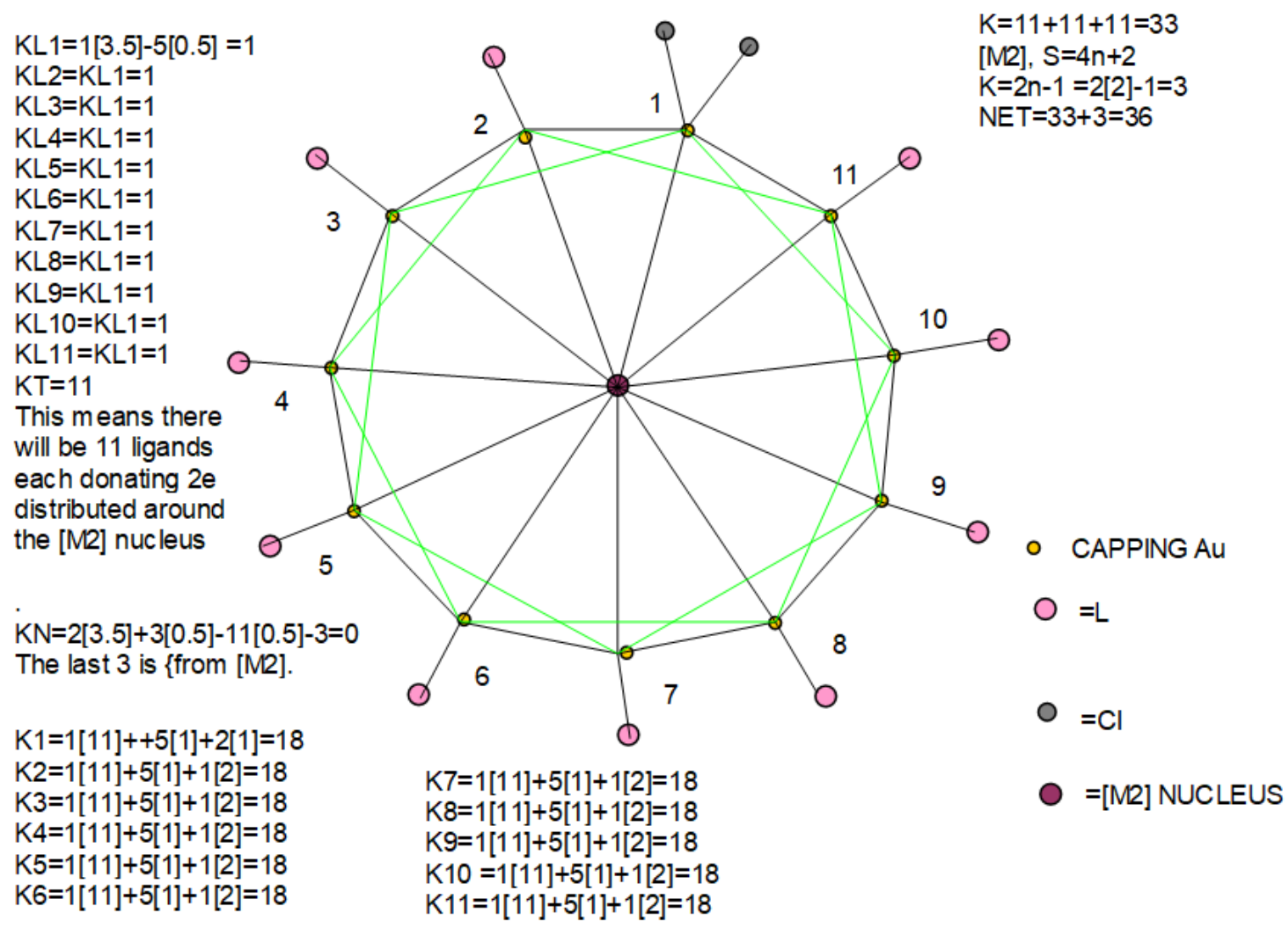

Figure 3B. The proposed isomeric graphical structure of $\mathrm{Au}_{13} \mathrm{Cl}_{2} \mathrm{~L} 10^{3+}$

On close scrutiny, the CVE literature formula $\mathrm{VE}=18+12 \mathrm{n}$ touched on an impressive infinite $\mathrm{K}(\mathrm{N})$ series of [M2] clan of clusters in which a good number of golden clusters are found. (Kiremire, 2018b). All the above examples which according to the $4 \mathrm{~N}$ of analysis do possess smaller clusters which act as nuclei belonging to the CLOSO family of clusters $\mathrm{S}=4 \mathrm{n}+2$ constitute a vast group of clusters.

Through the work with $4 \mathrm{~N}$ series, 4 fundamental and reliable cluster valence equations have emerged namely,

$$
\begin{aligned}
& \text { i. the series formula } V E=14 n+q ; \\
& \text { ii. the } K N \text { formula } V E=18 n-2 K \text {; } \\
& \text { iii. The Capping formula } V E=14+2 x+12(n-1) ; K p=C^{y} C[M x], y+x=n \\
& \text { iv. The genesis-capping formula } V E n=V_{0}+12 n \text {; where } V_{0}(n=0)
\end{aligned}
$$

These equations are applied to transition metal clusters and fragments.

The main group elements do have parallel ones which are given below.

$$
\begin{array}{ll}
\text { i. } & \mathrm{VE}=4 \mathrm{n}+\mathrm{q} \\
\text { ii. } & \mathrm{VE}=8 \mathrm{n}-2 \mathrm{~K} \\
\text { iii. } & \mathrm{VE}=4+2 \mathrm{x}+2(\mathrm{n}-1) \\
\text { iv. } & \mathrm{VE}=\mathrm{VE}_{0}+2 \mathrm{n}
\end{array}
$$

Although these equations have been mentioned in some publications (Kiremire, 2018c), it is important to be mentioned here as they are new and extremely useful and need to be popularized to more readers.

\subsection{The Side by Side Relationship of the Set of Nuclear Skeletal Elements [Mx] and That of the Capping Elements $C^{y}$}

This type of clusters is rare and one of them is $\mathrm{N}_{2}(\mathrm{AuL})_{6}{ }^{2+}: \mathrm{K}=19, \mathrm{~K}(\mathrm{n})=19(8), \mathrm{S}=4 \mathrm{n}-6, \mathrm{Kp}=2 \mathrm{n}+3, \quad \mathrm{Kp}=\mathrm{C}^{4} \mathrm{C}[\mathrm{M} 4]$ whose structure is analyzed and shown in Figure 4. The two nitrogen elements act as a bridge to link up the two sets of cluster skeletal elements. 

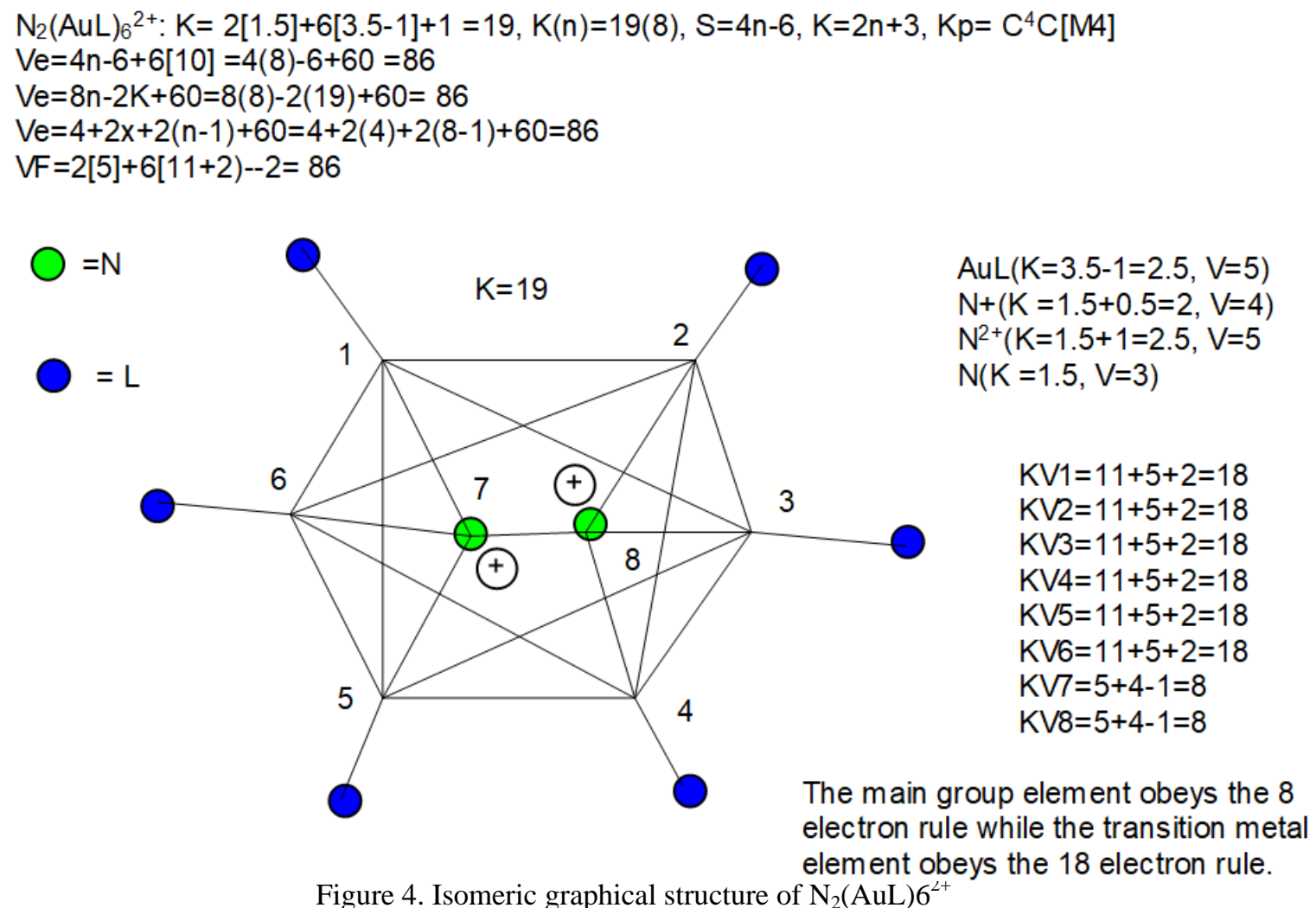

\section{The Genesis principle}

The genesis principle which is extremely important gives us the beginning of the capping series of a cluster. The starting point can easily be deduced from the capping symbol, in this case $\mathrm{Kp}=\mathrm{C}^{4} \mathrm{C}$ [M4]. The starting level of cluster valence electrons is given by $\mathrm{VE}_{0}=2 x+2$. The value of $x=$ the nuclear index in this case $x=4$. Hence, $V_{0}=2[4]+2=10$. The origin of this value can be explained further from the [M4] fragment which belongs to the CLOSO family of clusters, $\mathrm{S}=4 \mathrm{n}+2, \mathrm{~K}=2 \mathrm{n}-1=2[4]-1=7$. Hence the closo fragment has a $K(n)$ set $=7(4)$ which forms the $K(n)$ series: $7(4) \rightarrow 4(3) \rightarrow 1(2) \rightarrow-2(1) \rightarrow-5(0)$. This means that when $\mathrm{n}=0, \mathrm{~K}(\mathrm{n})=-5(0)$. We can now use the $\mathrm{KN}$ formula to determine the valence electrons $V E_{0}=8 n-2 K=8[0]-2[-5]=10$. This is the same value as obtained from $V E_{0}=2 x+2$ formula. We can also derive the valence electrons when the capping of the cluster reaches the closo level, that is, $V E_{C}=14 n+2=$ $14[4]+2=58$. Therefore, we can construct a diagram demonstrating the capping process to form the cluster, $\mathrm{N}_{2}(\mathrm{AuL})_{6}{ }^{2+}$. The capping process is also illustrated by the sketch given in Figure 5. The other way of visualizing it is as follows:

$\mathrm{F}=5 \mathrm{~L}+1\left[\mathrm{Au}^{-}\right]+1\left[\mathrm{Au}^{-}\right]+1\left[\mathrm{Au}^{-}\right]+1\left[\mathrm{Au}^{-}\right]+1\left[\mathrm{Au}^{-}\right]+1\left[\mathrm{Au}^{-}\right]+1\left[\mathrm{~N}^{3+}\right]+1\left[\mathrm{~N}^{3+}\right]=\left[\mathrm{N}_{2}\right]^{6+}[\mathrm{Au}]_{6}^{6-}+5 \mathrm{~L}=\mathrm{N}_{2} \mathrm{Au}_{6} \mathrm{~L}_{5}=\mathrm{N}_{2}(\mathrm{AuL})_{6}^{2+}$ The $5 \mathrm{~L}$ represent an equivalent of 10 electrons when $\mathrm{n}=0$.

The first 6 capping are involving transition metal elements and so we use fragments worth 12 electrons each $\left[\mathrm{Au}^{-}\right]$and the last two capping involve main group elements, so we have to use fragments worth 2 electrons each $\left[\mathrm{N}^{3+}\right]$. 


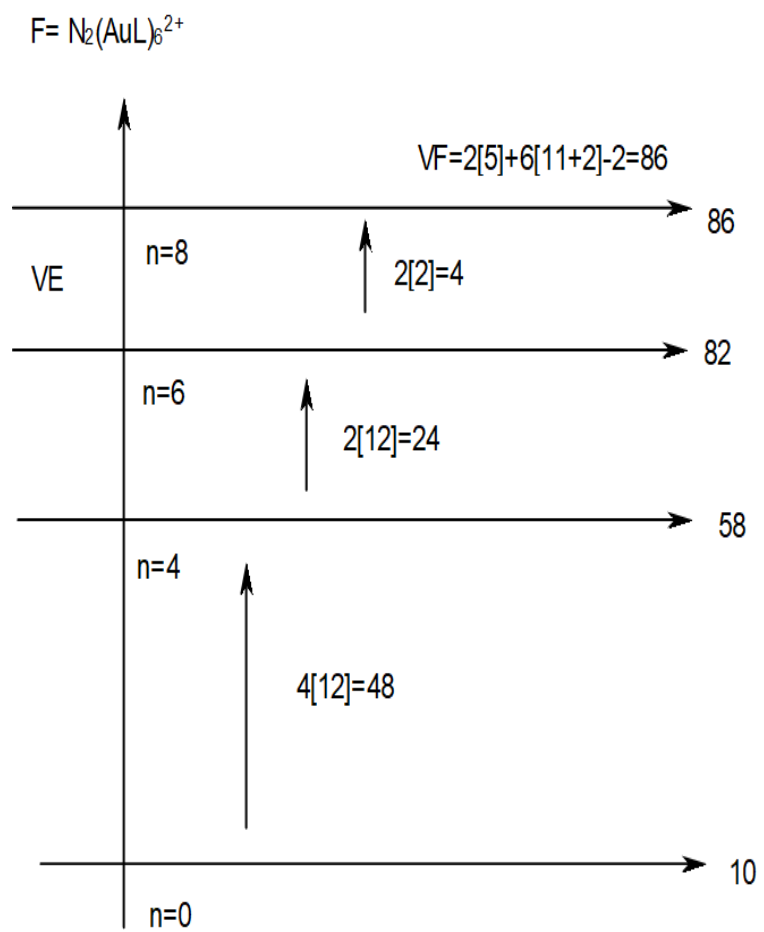

Figure 5. The proposed capping process of $\mathrm{N}_{2}(\mathrm{Aul}) 6^{2+}$

The genesis principle is so important that one or two more examples can be given to highlight this point. Let us take the cluster, $\mathrm{Au}_{6}(\mathrm{C}) \mathrm{L}_{6}{ }^{2+}$ (Fehlner \&Halet, 2007). The $\mathrm{K}$ value of the cluster $=6[3.5]-1[2]-6[1]+2[0.5]=14, \mathrm{~K}(\mathrm{n})=14(6)$, $\mathrm{S}=4 \mathrm{n}-4, \mathrm{~K}=2 \mathrm{n}+2, \mathrm{Kp}=\mathrm{C}^{3} \mathrm{C}[\mathrm{M} 3] ; \mathrm{VE}_{0}=2 \mathrm{x}+2(\mathrm{x}=3)=2[3]+2=8, \mathrm{VE}_{\mathrm{C}}=14 \mathrm{n}+2=14[3]+2=44$. Thus, according to the series method, the cluster has 3 skeletal elements at the nucleus surrounded by 3 capping elements. The capping process can be summed up in Figure 6A. This capping agrees with genesis capping principle $\mathrm{VE}=\mathrm{VE}_{0}+12 \mathrm{n}=8+12 \mathrm{n}$ as reported in literature (Fehlner \& Halet, 2007). Thus when $n=6, \mathrm{VE}=8+12[6]=80$. On the other hand when a cluster is an octahedral one, [M6]; such as $\mathrm{Rh}_{6}(\mathrm{CO})_{16}, \mathrm{~K}=6[4.5]-16[1]=11 ; \mathrm{K}(\mathrm{n})=11(6), \mathrm{S}=4 \mathrm{n}+2, \mathrm{~K}=2 \mathrm{n}-1, \mathrm{Kp}=\mathrm{C}^{0} \mathrm{C}[\mathrm{M} 6]$, then $\mathrm{VE}_{0}=2 \mathrm{x}+2$ $=2[6]+2=14$ and $\mathrm{VE}_{6}=14+12[6]=86$. The capping sketch is also given in Figure 6B.
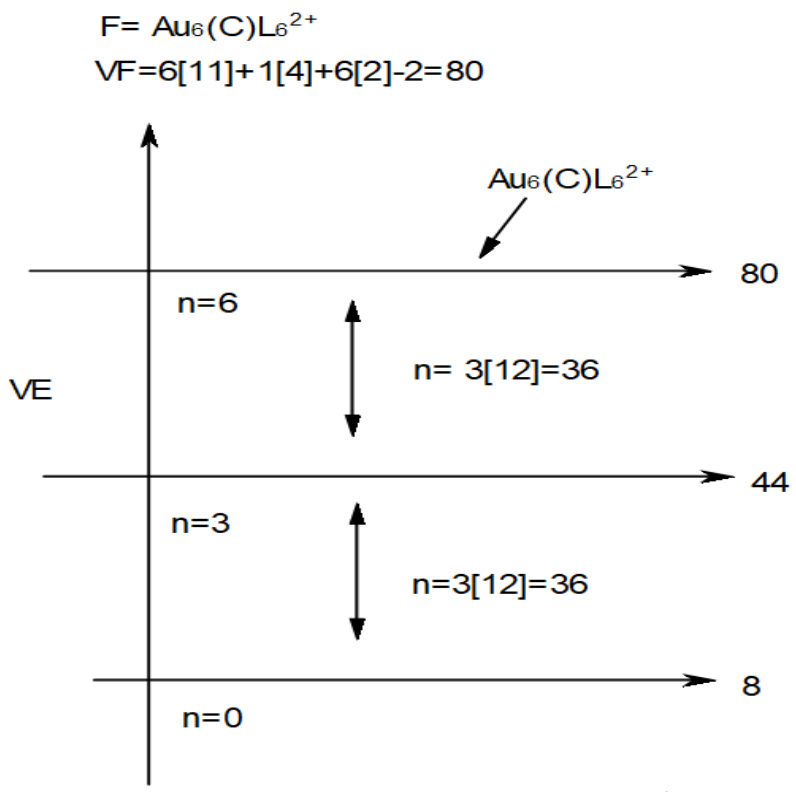

Figure 6A. The capping process of $\mathrm{Au}_{6}(\mathrm{C}) \mathrm{L}_{6}{ }^{2+}$ 


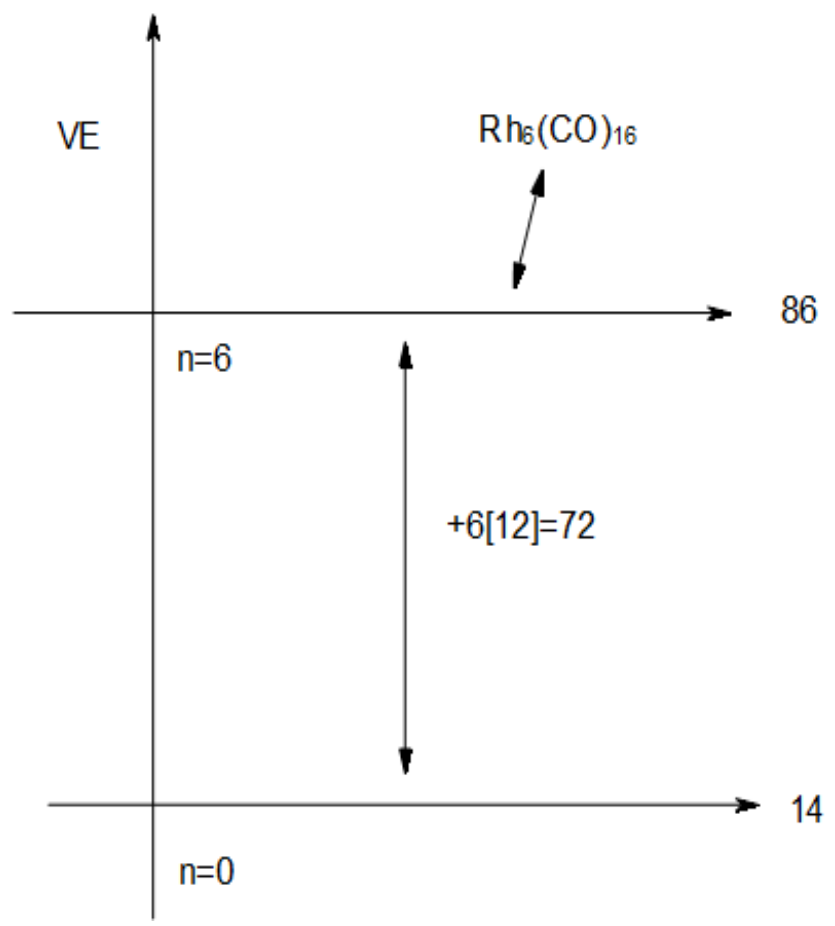

Figure 6B. The capping process for an octahedral fragment

\subsection{The Reversal of Positions: Capping Inside Out-Matryoshka Clusters}

A Matryoshka cluster can be represented a simple formula $\mathrm{A}_{21} \mathrm{~B}_{12}$, where $\mathrm{A}(\mathrm{K}=2)$ and $\mathrm{B}(\mathrm{K}=3)$. This combination results into a $\mathrm{K}(\mathrm{n})$ value of 78(33). However any suitable combination of $A$ and $B$ that gives the total $n=33$ and $K=78$ may produce a Matryoshka cluster based on series. The $K(n)$ parameter of the cluster is given by $K(n)=78(33), S=4 n-24$, $\mathrm{Kp}=\mathrm{C}^{13} \mathrm{C}[\mathrm{M} 20]$. According to the usual interpretation, this means the cluster has 20 skeletal elements in the nucleus and 13 of the remaining elements out of 33 are capping around the nucleus. What is observed in these Matryoshka clusters is an interesting phenomenon in which the 13 capping skeletal elements enter the cage-like structure of 20 skeletal elements and do the capping from the inside the cage. In addition, the 13 skeletal elements produce a well-known icosahedral geometry with one of the elements capping at the center of the cage. The interior cluster of 13 skeletal elements behave like a $\mathrm{B}_{12} \mathrm{H}_{12}{ }^{2-}$ cluster with an interstitial element in the nucleus. It appears that the elements with large $\mathrm{K}$ values and hence have more skeletal valences to them find it more suitable to settle inside the cage in order for them to easily link up with the neighboring skeletal elements. Sketches illustrating the concept of cluster genesis are given in Figures $6 \mathrm{C}$ and 7. In addition, isomeric graphical structures of selected Matryoshka clusters are represented in Figures 8 and 9: $\mathrm{As}_{21} \mathrm{Ni}_{12}{ }^{3-}$; Figure 10: $\mathrm{Sn}_{21} \mathrm{Mg}_{12}$; Figure 11: $\mathrm{Mn}_{12} \mathrm{Au}_{21}{ }^{123-}$; Figure 12: $\mathrm{Pb}_{21} \mathrm{Cu}_{12}{ }^{12-}$ and Figure 13: $\mathrm{Sn}_{21} \mathrm{Mn}_{12}{ }^{6-}$. These figures also illustrate how the connectivity principle can be applied to different types of skeletal elements. The details of the $4 \mathrm{~N}$ series analysis and categorization of the clusters are given in Scheme 1. 
$\mathrm{F}=\mathrm{Sn}_{21} \mathrm{Mg}_{12}: \mathrm{K}=21[2]+12[3]=78$

$\mathrm{K}(\mathrm{n})=78(33)$

$\mathrm{S}=4 \mathrm{n}-24$

$\mathrm{K}=2 \mathrm{n}+12$

$\mathrm{Kp}=\mathrm{C}^{13} \mathrm{C}[\mathrm{M} 20]$

$\mathrm{VE}_{0}=2 \mathrm{x}+2, \mathrm{x}=20 ; \mathrm{VE}_{0}=2[20]+2=42$

$\mathrm{VE}_{\mathrm{c}}=4 \mathrm{n}+2=4[20]+2=82$

$\mathrm{n}=20$

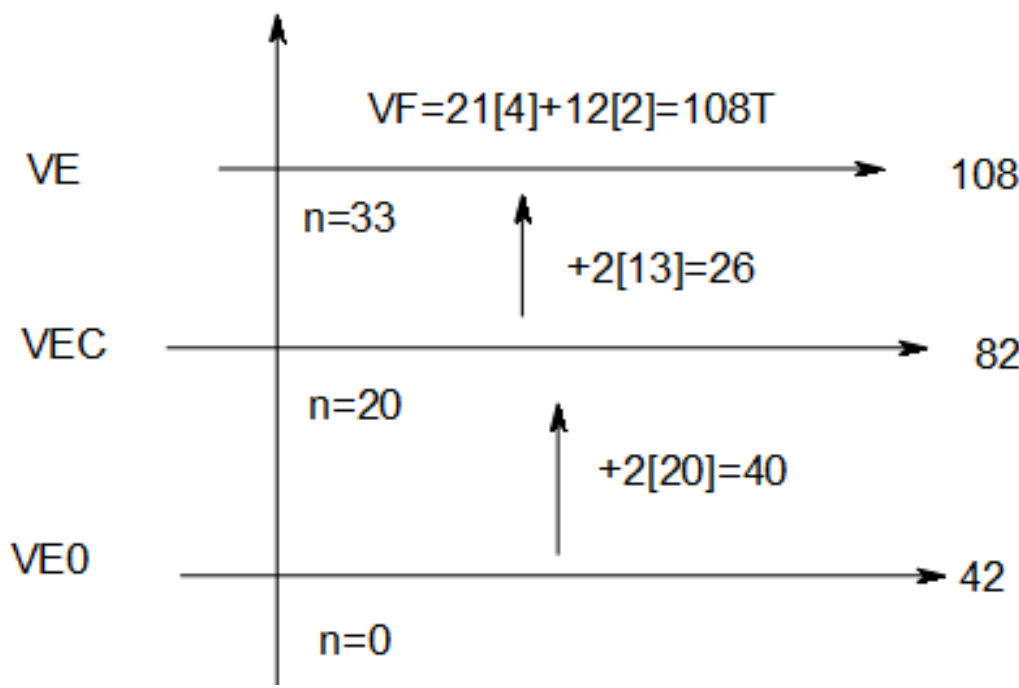

Figure 6C. The sketch of the capping process of the matryoshka cluster

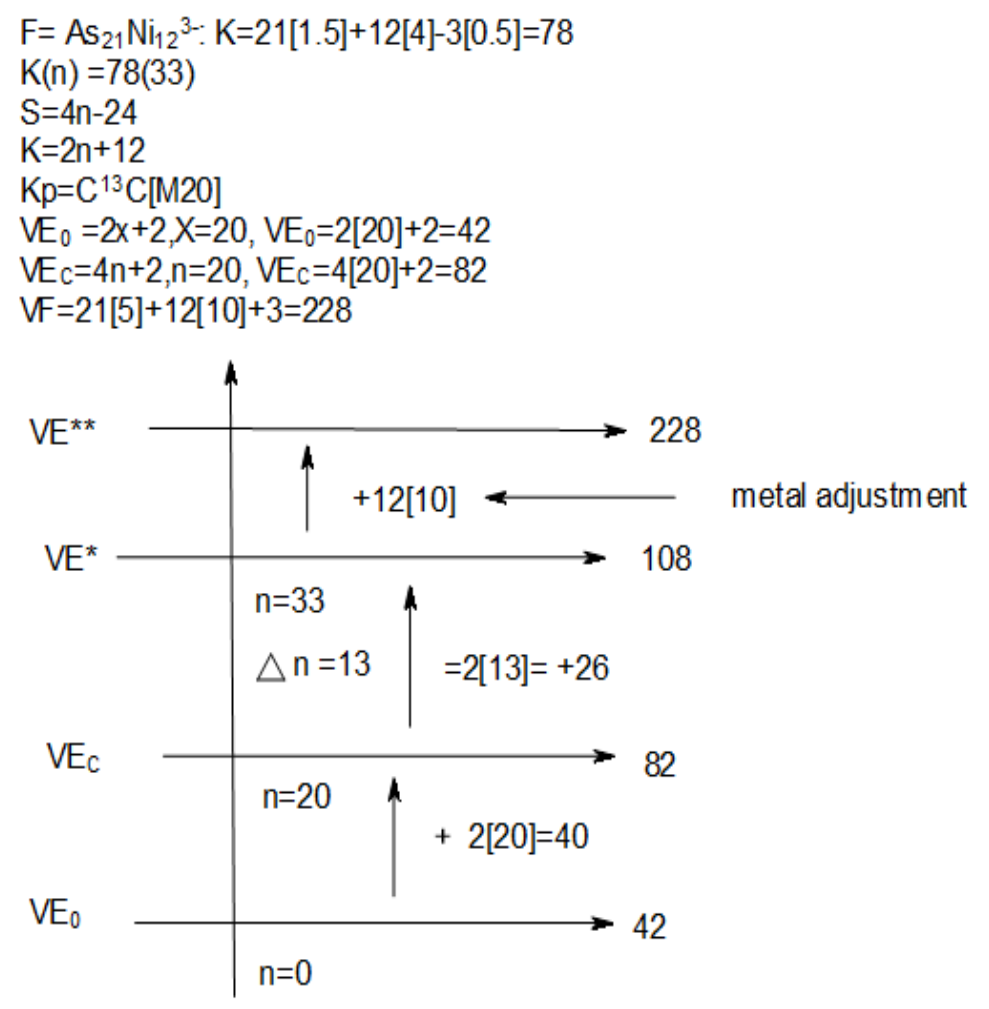

Figure 7. A sketch showing the capping process of a matryoshka cluster $\mathrm{As}_{21} \mathrm{Ni}_{12}{ }^{3-}$ 
$\mathrm{As}_{21} \mathrm{Ni}_{12}{ }^{3-} \quad \mathrm{K}=21[1.5]+12[4]-1.5=78, \mathrm{~K}(\mathrm{n})=78(33), \mathrm{S}=4 \mathrm{n}-24, \mathrm{~K}=2 \mathrm{n}+12, \mathrm{Kp}=\mathrm{C}^{13} \mathrm{C}[\mathrm{M} 20]$

$\mathrm{Ve}=4 \mathrm{n}-24+12[10]=4(33)-24+120=228$

$\mathrm{Ve}=8 \mathrm{n}-2 \mathrm{~K}+120=8(33)-2(78)+120=228$

$\mathrm{Ve}=4+2 \mathrm{x}+2(\mathrm{n}-1)+120=4+2(20)+2(32)+10(12)=228$,

$\mathrm{VF}=21[5]+12[10]+3=228$

PREDICTED

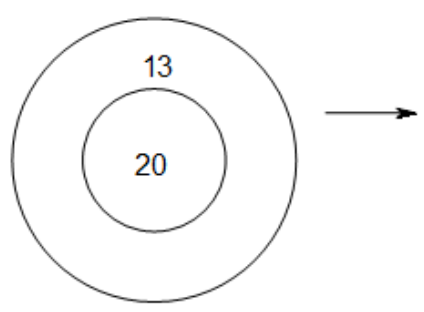

OBSERVED

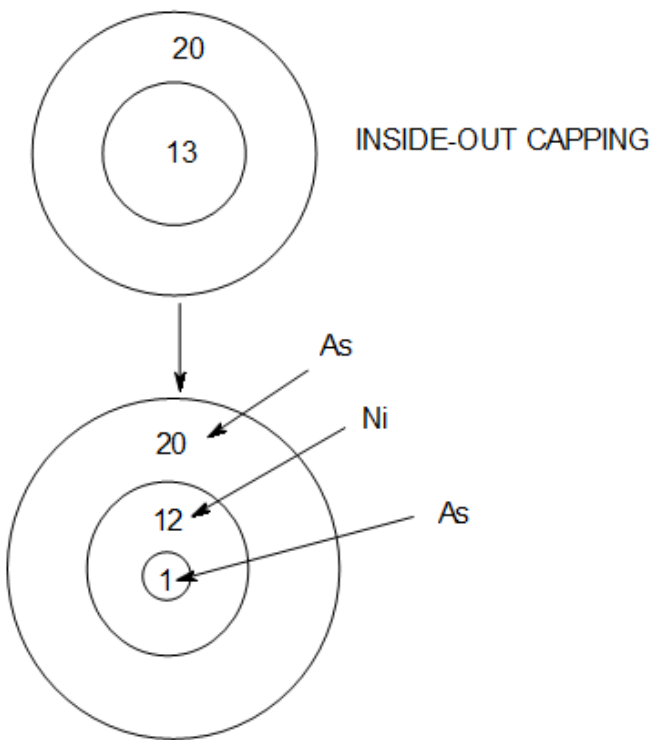

Figure 8. A visual representation of the layers of $\mathbf{A s}_{\mathbf{2 1}} \mathbf{N i}_{\mathbf{1 2}}{ }^{3-}$

$\mathrm{As}_{21} \mathrm{Ni}_{12}{ }^{2}: \mathrm{K}=78, \mathrm{~K}(\mathrm{n})=78(33), \mathrm{Kp}=\mathrm{C}^{13} \mathrm{C}[\mathrm{M} 20]$

$\mathrm{K}=78$

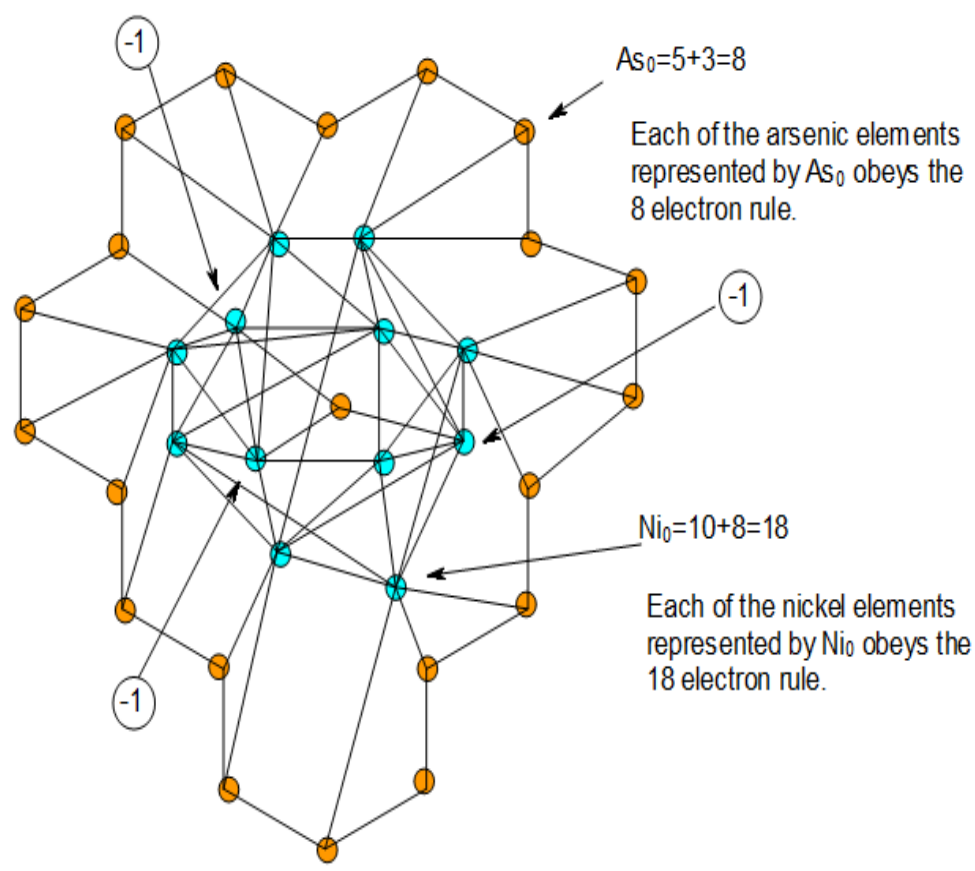

Figure 9. Isomeric graphical representation of $\mathrm{As}_{21} \mathrm{Ni}_{12}{ }^{3-}$ 
$\mathrm{Sn}_{21} \mathrm{Mg}_{12}: \mathrm{K}=21[2]+12[3]=78, \mathrm{~K}(\mathrm{n})=78(33), \mathrm{S}=4 \mathrm{n}-24, \mathrm{~K}=2 \mathrm{n}+12, \mathrm{Kp}=\mathrm{C}^{13} \mathrm{C}[\mathrm{M} 20]$ $\mathrm{Ve}=4 \mathrm{n}-24=4(33)-24=108, \mathrm{VF}=21[4]+12[2]=108$

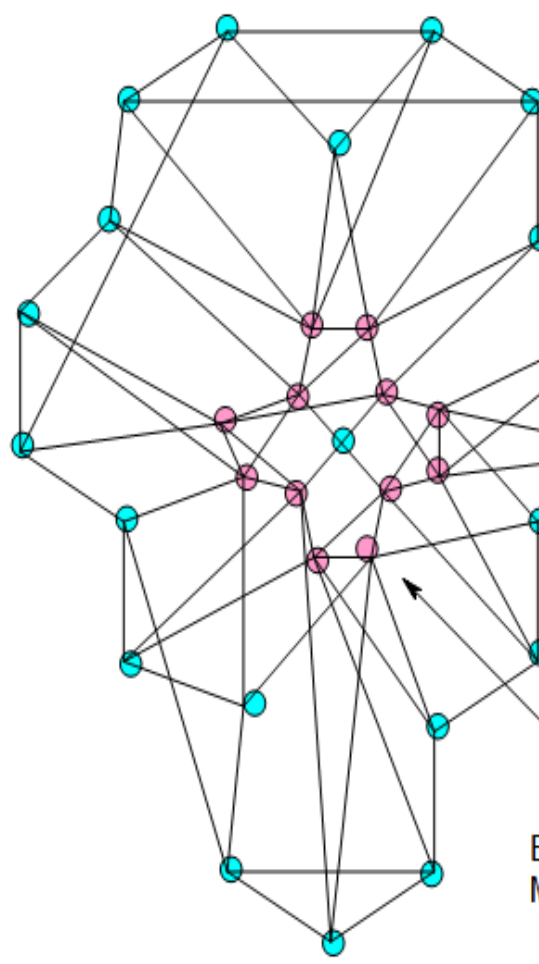

$\operatorname{Sn}(K=2, V=4)$

$\mathrm{Mg}(\mathrm{K}=3, \mathrm{~V}=6)$

○ $=\mathrm{Sn}$

$\mathrm{O}=\mathrm{Mg}$

$\mathrm{Sn}_{0}=4+4=8$

Each of the tin elements represented by $\mathrm{Sn}_{0}$ obeys the 8 electron rule.

Figure 10. Isomeric graphical structure of $\mathrm{Mg}_{12} \mathrm{Sn}_{21}$

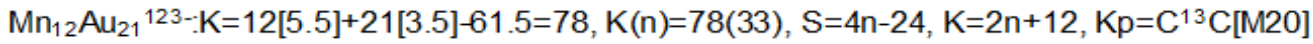

$\mathrm{Ve}=14 \mathrm{n}-24=14(33)-24=438$

$\mathrm{VF}=12[7]+21[11]+123=438$

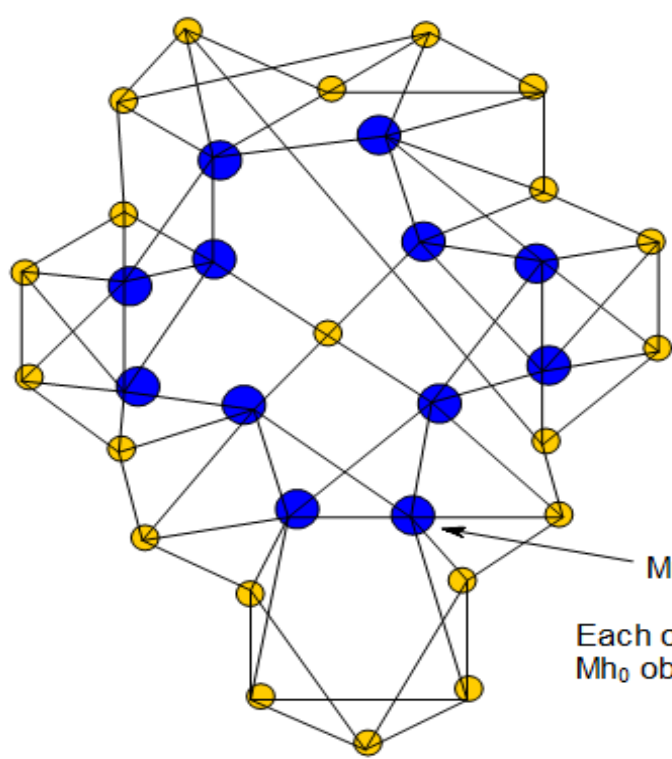

$=\mathrm{Au}^{3}-(\mathrm{K}=3.5-1.5=2, \mathrm{~V}=4)$

$=\mathrm{Mn}^{5}-(\mathrm{K}=5.5-2.5=3, \mathrm{~V}=6)$

Each of the magnessium elements represented by

Mgo obeys the 8 electron rule.

$M g_{0}=2+6=8$

Figure 11. Isomeric graphical structure of $\mathrm{Mn}_{12} \mathrm{Au}_{21}{ }^{123-}$ 


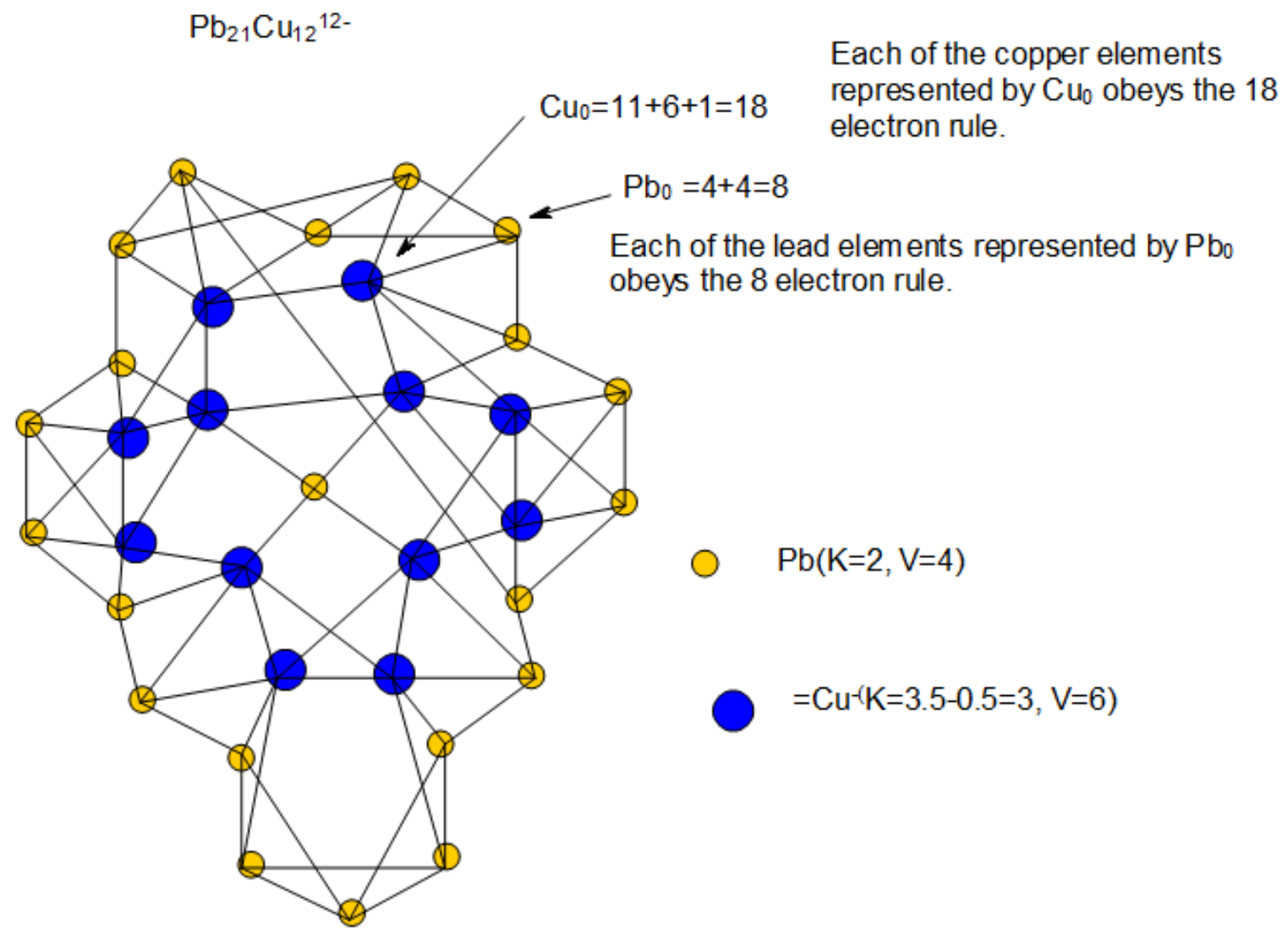

Figure 12. Isomeric graphical structure of $\mathrm{Pb}_{21} \mathrm{Cu}_{12}{ }^{12-}$

$\mathrm{Sn}_{21} \mathrm{Mn}_{12}{ }^{60-}$

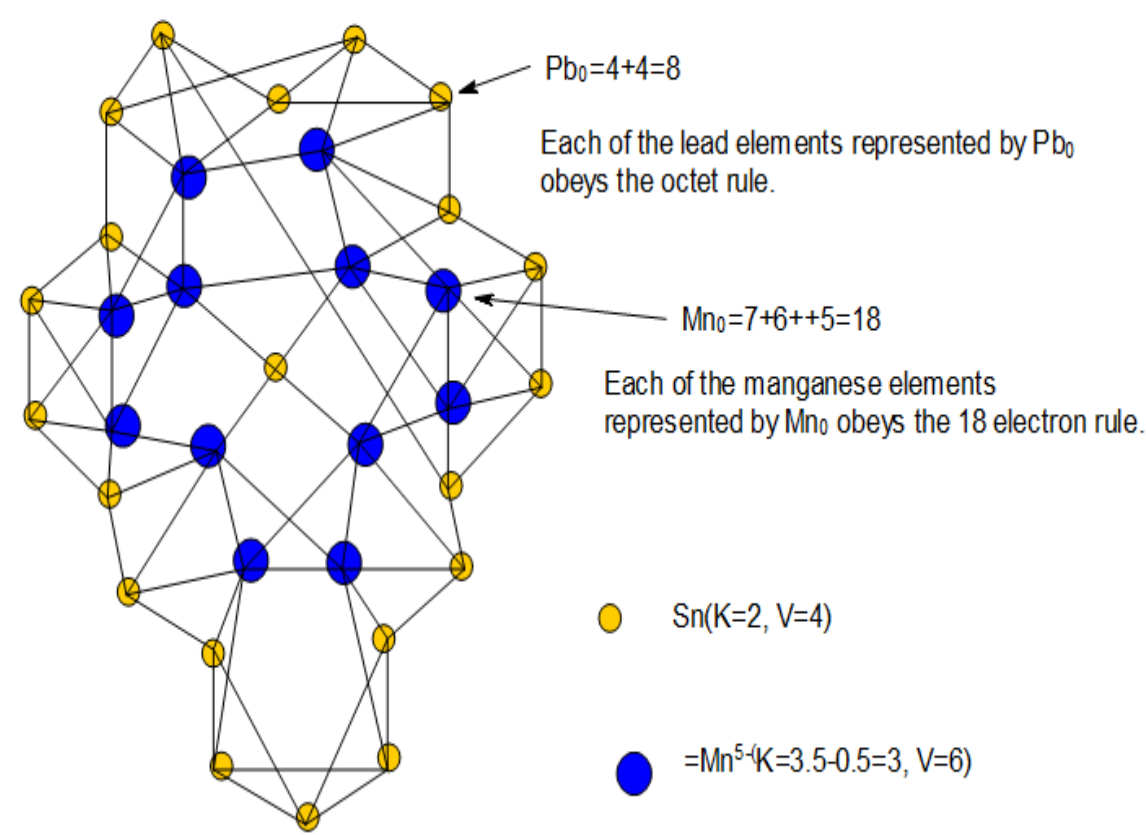

Figure 13. Isomeric graphical structure of $\mathrm{Sn}_{21} \mathrm{Mn}_{12}{ }^{60-}$ 
The isomeric skeletal graphical structures have been constructed according to the connectivity principle following the valence rule or linkages associated with individual skeletal elements in the cluster. Clearly, the Matryoshka clusters also obey the $18 / 8$ rule accordingly.

$\mathrm{Sn}_{21} \mathrm{Cu}_{12}{ }^{12-}$

$\mathrm{K}=21[2]+12[3.5]-6=78$

$\mathrm{K}(\mathrm{n})=78(33)$

$\mathrm{S}=4 \mathrm{n}-24, \mathrm{~K}=2 \mathrm{n}+12$,

$\mathrm{Kp}=\mathrm{C}^{13} \mathrm{C}[\mathrm{M} 20]$

The capping symbol tells us that there are two sets of skeletal elements; the nucleus of 20 and the capping set of 13.Unlike many capping clusters, instead of the normal capping outside, here the capping acts as a nucleus.

$\mathrm{Ve}=4 \mathrm{n}-24+12[10]=228$

$\mathrm{VF}=21[4]+12[11]+12=228$

$\mathrm{Ve}=4+2(20)+2(32)+10(12)=228, \mathrm{VF}=21[4]+12[11]+12=228$

$\mathrm{Sn}_{21} \mathrm{Mg}_{12}$

$\mathrm{K}=21[2]+12[3]=78$

$\mathrm{K}(\mathrm{n})=78(33)$

$\mathrm{S}=4 \mathrm{n}-24$

$\mathrm{K}=2 \mathrm{n}+12$

$\mathrm{Kp}=\mathrm{C}^{13} \mathrm{C}[\mathrm{M} 20]$

The capping symbol predicts a Matryoshka cluster.

$\mathrm{Ve}=4+2(20)+2(32)=108$

$\mathrm{VF}=21[4]+12[2]=108$

$\mathrm{Mn}_{13} \mathrm{Au}_{12}{ }^{-}$

$\mathrm{K}=13[5.5]+12[3.5]-0.5=113$,

$\mathrm{K}(\mathrm{n})=113(25)$

$\mathrm{S}=4 \mathrm{n}-126$

$\mathrm{K}=2 \mathrm{n}+63$

$\mathrm{Kp}=\mathrm{C}^{64} \mathrm{C}[\mathrm{M}-39]$

$\mathrm{Ve}=14+2(-39)+12(24)=224$

$\mathrm{VF}=13[7]+12[11]+1=224$

The capping symbol is not in agreement with a Matryoshka structure.

$$
\mathrm{Mn}_{12} \mathrm{Au}_{21}{ }^{-123}
$$

$\mathrm{K}=12[5.5]+21[3.5]-61.5=78$

$\mathrm{K}(\mathrm{n})=78(33)$

$\mathrm{S}=4 \mathrm{n}-24$

$\mathrm{K}=2 \mathrm{n}+12$

$\mathrm{Kp}=\mathrm{C}^{13} \mathrm{C}[\mathrm{M} 20]$

The capping symbol is predicting a Matryoshka cluster.

$\mathrm{Ve}=14+2(20)+12(32)=438$ 
$\mathrm{VF}=12[7]+21[11]+123=438$

$\mathrm{Pb}_{21} \mathrm{Mn}_{12}$

$\mathrm{K}=21[2]+12[5.5]=108$

$\mathrm{K}(\mathrm{n})=108(33)$

$\mathrm{S}=4 \mathrm{n}-84$

$\mathrm{K}=2 \mathrm{n}+42$

$\mathrm{Kp}=\mathrm{C}^{43} \mathrm{C}[\mathrm{M}-10]$

$\mathrm{Ve}=4+2(-10)+2(32)+10(12)=168$

$\mathrm{VF}=21[4]+12[7]=168$

The capping symbol is not in agreement with a Matryoshka structure

$\mathrm{Sn}_{21} \mathrm{Cu}_{12}{ }^{12-}$

$\mathrm{K}=21[2]+12[3.5]-6=78$

$\mathrm{K}(\mathrm{n})=78(33)$

$\mathrm{S}=4 \mathrm{n}-24$

$\mathrm{K}=2 \mathrm{n}+12$

$\mathrm{Kp}=\mathrm{C}^{13} \mathrm{C}[\mathrm{M} 20]$

The capping symbol is predicting a Matryoshka cluster

$\mathrm{Sn}_{21} \mathrm{Mn}_{12}: \mathrm{K}=21[2]+12[5.5]=108, \mathrm{~K}(\mathrm{n})=108(33), \mathrm{S}=4 \mathrm{n}-84, \mathrm{~K}=2 \mathrm{n}+42, \mathrm{Kp}=\mathrm{C}^{43} \mathrm{C}[\mathrm{M}-10]$

$\mathrm{Sn}_{21} \mathrm{Mn}_{12}{ }^{60-}: \mathrm{K}=21[2]+12[5.5]-30=78, \mathrm{~K}(\mathrm{n})=78(33), \mathrm{S}=4 \mathrm{n}-24, \mathrm{~K}=2 \mathrm{n}+12, \mathrm{Kp}=\mathrm{C}^{13} \mathrm{C}[\mathrm{M} 20]$

$\mathrm{Ve}=4 \mathrm{n}-24+12[10]=4(33)-24+120=228$

$\mathrm{VF}=21[4]+12[7]+60=228$

Scheme 1. Identification of Matryoshka cluster series

\subsection{Designing Hypothetical Matryonika Clusters Using Series}

With the knowledge that a Matryoshka cluster has a general formula $A_{21} B_{12}$ where $A$ has a $K$ value of 2 and $B$ a $K$ value of 3 or their equivalents. With the guidance of the $4 \mathrm{~N}$ series method and the appropriate skeletal numbers to generate $K(n)=78(33), S=4 n-24, K=2 n+12, K p=C^{13} C[M 20]$, hypothetical formulas of examples of skeletal elements that could portray Motryoshka structures can be proposed. These are given in Table 7. The table includes the well- known Matrtoshka clusters $\mathrm{As}_{21} \mathrm{Ni}_{12}{ }^{3-}$ and $\mathbf{S n}_{21} \mathbf{C u}_{12}{ }^{12-}$ (Huang, et al,2014). 
Table 7. Hypothetically formulated Matryoshka custers and some of the known ones

\begin{tabular}{|c|c|c|c|c|c|c|}
\hline $\mathrm{B}_{12} \mathrm{~A}_{21}$ & & $\mathrm{~K}(\mathrm{n})$ & $S=4 n+q$ & $\begin{array}{l}K=2 n- \\
1 / 2 q\end{array}$ & $\mathrm{Kp}=\mathrm{C}^{\mathrm{y}} \mathrm{C}[\mathrm{Mx}]$ & $\begin{array}{l}\mathrm{Ve}^{*}= \\
\mathrm{a}+\mathrm{b}+\mathrm{c}+\mathrm{d}\end{array}$ \\
\hline & $\mathrm{K}=78$ & $78(33)$ & $4 n-24$ & $2 n+12$ & $\mathrm{C}^{13} \mathrm{C}[\mathrm{M} 20]$ & \\
\hline$\left(\mathrm{Sc}^{9-}\right)_{12} \mathrm{Sn}_{21}$ & $\mathrm{Sc}_{12} \mathrm{Sn}_{21}{ }^{108-}$ & $78(33)$ & $4 n-24$ & $2 n+12$ & $\mathrm{C}^{13} \mathrm{C}[\mathrm{M} 20]$ & 228 \\
\hline$\left(\mathrm{Ti}^{8-}\right)_{12} \mathrm{Sn}_{21}$ & $\mathrm{Ti}_{12} \mathrm{Sn}_{21}{ }^{96-}$ & $78(33)$ & $4 n-24$ & $2 n+12$ & $\mathrm{C}^{13} \mathrm{C}[\mathrm{M} 20]$ & 228 \\
\hline$\left(\mathrm{V}^{7-}\right)_{12} \mathrm{Sn}_{21}$ & $\mathrm{~V}_{12} \mathrm{Sn}_{21}{ }^{84-}$ & $78(33)$ & $4 n-24$ & $2 n+12$ & $\mathrm{C}^{13} \mathrm{C}[\mathrm{M} 20]$ & 228 \\
\hline$\left(\mathrm{Cr}^{6-}\right)_{12}\left(\mathrm{As}^{+}\right)_{21}$ & $\mathrm{Cr}_{12} \mathrm{As}_{21}{ }^{51-}$ & $78(33)$ & $4 n-24$ & $2 n+12$ & $\mathrm{C}^{13} \mathrm{C}[\mathrm{M} 20]$ & 228 \\
\hline$\left(\mathrm{Mn}^{5-}\right)_{12}\left(\mathrm{As}^{+}\right)_{21}$ & $\mathrm{Mn}_{12} \mathrm{As}_{21}{ }^{39-}$ & $78(33)$ & $4 n-24$ & $2 n+12$ & $\mathrm{C}^{13} \mathrm{C}[\mathrm{M} 20]$ & 228 \\
\hline$\left(\mathrm{Ni}^{2-}\right)_{12}\left(\mathrm{As}^{+}\right)_{21}$ & $\mathrm{Ni}_{12} \mathrm{As}_{21}{ }^{3-}$ & $78(33)$ & $4 n-24$ & $2 n+12$ & $\mathrm{C}^{13} \mathrm{C}[\mathrm{M} 20]$ & 228 \\
\hline$\left(\mathrm{Co}^{3-}\right)_{12}\left(\mathrm{As}^{+}\right)_{21}$ & $\mathrm{Co}_{12} \mathrm{As}_{21}{ }^{15-}$ & $78(33)$ & $4 n-24$ & $2 n+12$ & $\mathrm{C}^{13} \mathrm{C}[\mathrm{M} 20]$ & 228 \\
\hline$\left(\mathrm{Cu}^{-}\right)_{12}(\mathrm{Sn})_{21}$ & $\mathrm{Cu}_{12} \mathrm{Sn}_{21}{ }^{12-}$ & $78(33)$ & $4 n-24$ & $2 n+12$ & $\mathrm{C}^{13} \mathrm{C}[\mathrm{M} 20]$ & 228 \\
\hline$(\mathrm{Zn})_{12}(\mathrm{Sn})_{21}$ & $\mathrm{Zn}_{12} \mathrm{Sn}_{21}$ & $78(33)$ & $4 n-24$ & $2 n+12$ & $\mathrm{C}^{13} \mathrm{C}[\mathrm{M} 20]$ & 228 \\
\hline$(\mathrm{Mg})_{12}(\mathrm{Sn})_{21}$ & $\mathrm{Mg}_{12} \mathrm{Sn}_{21}$ & $78(33)$ & $4 n-24$ & $2 n+12$ & $\mathrm{C}^{13} \mathrm{C}[\mathrm{M} 20]$ & 108 \\
\hline$\left(\mathrm{Cu}^{-}\right)_{12}\left(\mathrm{Sb}^{+}\right)_{21}$ & $\mathrm{Cu}_{12} \mathrm{Sb}_{21}{ }^{9+}$ & $78(33)$ & $4 n-24$ & $2 n+12$ & $\mathrm{C}^{13} \mathrm{C}[\mathrm{M} 20]$ & 228 \\
\hline$(\mathrm{Zn})_{12}\left(\mathrm{Bi}^{+}\right)_{21}$ & $\mathrm{Zn}_{12} \mathrm{Bi}_{21}{ }^{21+}$ & $78(33)$ & $4 n-24$ & $2 n+12$ & $\mathrm{C}^{13} \mathrm{C}[\mathrm{M} 20]$ & 228 \\
\hline$(\mathrm{Hg})_{12}(\mathrm{~Pb})_{21}$ & $\mathrm{Hg}_{12} \mathrm{~Pb}_{21}$ & $78(33)$ & $4 n-24$ & $2 n+12$ & $\mathrm{C}^{13} \mathrm{C}[\mathrm{M} 20]$ & 228 \\
\hline$(\mathrm{Ca})_{12}\left(\mathrm{Si}_{21}\right.$ & $\mathrm{Ca}_{12} \mathrm{Si}_{21}$ & $78(33)$ & $4 n-24$ & $2 n+12$ & $\mathrm{C}^{13} \mathrm{C}[\mathrm{M} 20]$ & 108 \\
\hline$\left(\mathrm{Li}^{-}\right)_{12}\left(\mathrm{Se}^{2+}\right)_{21}$ & $\mathrm{Li}_{12} \mathrm{Se}_{21}{ }^{30+}$ & $78(33)$ & $4 n-24$ & $2 n+12$ & $\mathrm{C}^{13} \mathrm{C}[\mathrm{M} 20]$ & 108 \\
\hline$\left(\mathrm{Ni}^{2-}\right)_{12}\left(\mathrm{Te}^{2+}\right)_{21}$ & $\mathrm{Ni}_{12} \mathrm{Te}_{21}{ }^{18+}$ & $78(33)$ & $4 n-24$ & $2 n+12$ & $\mathrm{C}^{13} \mathrm{C}[\mathrm{M} 20]$ & 228 \\
\hline$\left(\mathrm{Fe}^{4-}\right)_{12}(\mathrm{Ge})_{21}$ & $\mathrm{Fe}_{12} \mathrm{Ge}_{21}{ }^{4-}$ & $78(33)$ & $4 n-24$ & $2 n+12$ & $\mathrm{C}^{13} \mathrm{C}[\mathrm{M} 20]$ & 228 \\
\hline$(\mathrm{Hg})_{12}\left(\mathrm{Te}^{2+}\right)_{21}$ & $\mathrm{Hg}_{12} \mathrm{Te}_{21}{ }^{42+}$ & $78(33)$ & $4 n-24$ & $2 n+12$ & $\mathrm{C}^{13} \mathrm{C}[\mathrm{M} 20]$ & 228 \\
\hline$(\mathrm{Cd})_{12}\left(\mathrm{P}^{+}\right)_{21}$ & $\mathrm{Cd}_{12} \mathrm{P}_{21}{ }^{21+}$ & $78(33)$ & $4 n-24$ & $2 n+12$ & $\mathrm{C}^{13} \mathrm{C}[\mathrm{M} 20]$ & 228 \\
\hline$\left(\mathrm{Co}^{3-}\right)_{12}\left(\mathrm{Te}^{2+}\right)_{21}$ & $\mathrm{Co}_{12} \mathrm{Te}_{21}{ }^{6+}$ & $78(33)$ & $4 n-24$ & $2 n+12$ & $\mathrm{C}^{13} \mathrm{C}[\mathrm{M} 20]$ & 228 \\
\hline
\end{tabular}

\section{The Existence of Magic Numbers}

The presence of the Magic Number 108 (Fehlner \& Halet, 2007) was mentioned in connection with the Matryoshka clusters. This magic number stated as 108 can be explained by the capping-genesis principle and cluster valence rules. For example the cluster, $\mathrm{F}=\mathrm{Sn}_{21} \mathrm{Mg}_{12}, \mathrm{~K}=21[2]+12[3]=78, \mathrm{n}=21+12=33, \mathrm{~K}(\mathrm{n})=78(33), \mathrm{S}=4 \mathrm{n}-24, \mathrm{~K}=2 \mathrm{n}+12, \mathrm{Kp}=$ $\mathrm{C}^{13} \mathrm{C}[\mathrm{M} 20] ; \mathrm{VE}_{0}=2 \mathrm{x}+2, \mathrm{x}=20$ and hence $\mathrm{K}=2[20]+2=42(\mathrm{n}=0), \mathrm{VE}_{\mathrm{C}}=4 \mathrm{n}+2=4[20]+2=82$. The capping follows an arithmetic progression and can be expressed as $\mathrm{VE}=\mathrm{VE}_{0}+2 \mathrm{n}$ (for main group elements). This becomes $\mathrm{VE}=42+2[33]=$ 108.The magic number can also be calculated using one of the series cluster valence electrons s formula such as $\mathrm{VE}=4 \mathrm{n}-24=4(33)-24=108$. However, when the cluster comprises of a mixture of main group and transition metal elements, the equation has to be adjusted to accommodate both types of elements. Such type of a cluster is $\mathrm{F}=\mathrm{As}_{21} \mathrm{Ni}_{12}{ }^{3-} ; \mathrm{K}(\mathrm{N})=78(33), \mathrm{S}=4 \mathrm{n}-24, \mathrm{~K}=2 \mathrm{n}+12, \mathrm{Kp}=\mathrm{C}^{13} \mathrm{C}[\mathrm{M} 20]$. According to the series the starting BASE cluster valence electrons are the same for both main group and transition elements ,in this case, $\mathrm{VE}_{0}=42$. Judging from the cluster formula, we have two types of capping, for the main group elements, capping electrons= [2] and transition elements capping electrons $=[12]$. Hence, $\mathrm{VE}=42+2[21]$

$+12[12]=42+2[21]+12[2+10]=42+2[21]+12[2]+12[10]=42+42+24+120=108+120=228$. Again, we can see that the magic number 108 is hiding within 228, the valence electrons of the cluster. Even when the Matryoshka cluster comprises of only transition elements, the magic number can still be identified as in the case of $\mathrm{F}=\mathrm{Mn}_{12} \mathrm{Au}_{21}{ }^{123-}$; $\mathrm{K}=78, \mathrm{~K}(\mathrm{n})=78(33), \mathrm{Kp}=\mathrm{C}^{13} \mathrm{C}[\mathrm{M} 20]$. For this cluster,

$\mathrm{VE}=42+33[12]=42+33[2+10]=42+33[2]+33[10]=42+66+330=108+330=438$. The magic number is also present. However, the presence of 108 magic number was attributed to existence of $\mathrm{I}_{\mathrm{h}}$ symmetry in the cluster (Huang, et al, 2014). In matryoshka clusters, it can be seen that the skeletal elements which are supposed to be the nucleus [m20] are actually in the outside layer and the 13 capping elements have taken the place of the nucleus. Hence, the term "inside out capping" is appropriate. What is interesting is that in case of $\mathrm{As}_{21} \mathrm{Ni}_{12}{ }^{3-}$ Matryoshka cluster, the thirteen capping elements inside include ONE arsenic main group element at the CENTRE of the 12 nickel elements while the remaining 20 skeletal elements reside outside the cluster. This gives rise to 3 layers of 1:12:20 in increasing size and the name MATRYOSHKA is therefore an appropriate description. This information is summed up in Figure 8 presented earlier.

$* a=4$ (main group), 14(transition metal; $b=2 x(x=$ capping index), $c=2(n-1)$, main group, 12(n-1) transition metal, $\mathrm{d}=$ metal adjustment term where needed.

Example: $\mathrm{Ve}=4+2(20)+2(32)+10(12)=228$

$\mathrm{K}=2$ : C, $\mathrm{Si}, \mathrm{Ge}, \mathrm{Sn}, \mathrm{Pb}, \mathrm{N}+, \mathrm{P}^{+}, \mathrm{As}^{+}, \mathrm{Sb}^{+}, \mathrm{Bi}^{+}, \mathrm{S}^{2+}, \mathrm{Se}^{2+}, \mathrm{Te}^{2+}$

$\mathrm{K}=3: \mathrm{Sc}^{9-}, \mathrm{V}^{7-}, \mathrm{Cr}^{6-}, \mathrm{Ti}^{8-}, \mathrm{Mn}^{5-}, \mathrm{Fe}^{4-}, \mathrm{Co}^{3-}, \mathrm{Ni}^{2-}, \mathrm{Cu}^{-}, \mathrm{Zn}, \mathrm{Cd}, \mathrm{Hg}, \mathrm{Mg}, \mathrm{Ca}, \mathrm{Li}^{-}$ 


\section{Conclusions}

The Matryoshka clusters belong to a new type of cluster series in which the capping phenomena are inside out. In addition, they form a unique type of nucleus which has got an icosahedral symmetry which also has a nucleus. They have been represented by a symbol $\mathrm{A}_{0} \mathrm{~B}_{12} @ \mathrm{~A}_{20}$ based on the structural arrangement. These clusters also obey the law of skeletal numbers and their valences. Simple graphical representations of their structures have been introduced. When the graphs are constructed properly each of the main group elements obeys the 8 electron rule while in case of transition metals each of the elements obeys the 18 electron rule.

\section{Acknowledgements}

The editing of the draft by Dr. P.E.T. Kiremire is greatly appreciated. The hospitality of Serene Suites Hotel, Mutundwe has enormously contributed to the completion of this paper.

\section{Appendix-1}

\section{APPENDIX-2}

\begin{tabular}{c|c|c|c|c|c|c|c|c}
\hline \multicolumn{9}{c}{ Skeletal k Values of Main Group Elements } \\
\hline Group & Ve & Series, $\mathbf{S}=\mathbf{4 n + q}$ & $\mathrm{K}=\mathbf{2 n - q} / \mathbf{2}$ & & & & & \\
\hline 1 & 1 & $4 n-3$ & 3.5 & Li & Na & K & Rb & Cs \\
\hline 2 & 2 & $4 n-2$ & 3 & Be & Mg & Ca & Sr & Ba \\
\hline 3 & 3 & $4 n-1$ & 2.5 & B & Al & Ga & In & Tl \\
\hline 4 & 4 & $4 n+0$ & 2 & C & Si & Ge & Sn & Pb \\
\hline 5 & 5 & $4 n+1$ & 1.5 & N & P & As & Sb & Bi \\
\hline 6 & 6 & $4 n+2$ & 1 & O & S & Se & Te & Po \\
\hline 7 & 7 & $4 n+3$ & 0.5 & F & Cl & Br & I & At \\
\hline 8 & 8 & $4 n+4$ & 0 & Ne & Ar & Kr & Xe & Rn \\
\hline
\end{tabular}

\begin{tabular}{|c|c|c|c|c|c|}
\hline \multicolumn{6}{|c|}{ Skeletal K Values of Transition Metals } \\
\hline $\begin{array}{l}\text { 3d-T } \\
\mathbf{M}^{*}\end{array}$ & $\begin{array}{l}\text { 4d - } \\
\text { TM* }\end{array}$ & Ve & $\begin{array}{l}\text { 5d-T } \\
M^{*}\end{array}$ & $\begin{array}{c}\text { Series, } S= \\
4 n+q\end{array}$ & $K=2 n-q / 2$ \\
\hline Sc & $\mathbf{Y}$ & 3 & La & 4n-11 & 7.5 \\
\hline Ti & $\mathbf{Z r}$ & 4 & Hf & $4 n-10$ & 7 \\
\hline $\mathbf{V}$ & $\mathbf{N b}$ & 5 & Ta & $4 n-9$ & 6.5 \\
\hline $\mathbf{C r}$ & Mo & 6 & $\mathbf{W}$ & $4 n-8$ & 6 \\
\hline Mn & Tc & 7 & $\mathbf{R e}$ & $4 n-7$ & 5.5 \\
\hline $\mathbf{F e}$ & $\mathbf{R u}$ & 8 & Os & $4 n-6$ & 5 \\
\hline Co & $\mathbf{R h}$ & 9 & $\mathbf{I r}$ & $4 n-5$ & 4.5 \\
\hline $\mathbf{N i}$ & Pd & 10 & $\mathbf{P t}$ & $4 n-4$ & 4 \\
\hline $\mathbf{C u}$ & $\mathbf{A g}$ & 11 & $\overline{\mathbf{A u}}$ & $4 n-3$ & 3.5 \\
\hline $\mathrm{Zn}$ & $\mathbf{C d}$ & 12 & $\mathbf{H g}$ & $4 n-2$ & 3 \\
\hline
\end{tabular}

\section{References}

Esenturk, E. N., Fettinger, J., \& SEichhorn, B. (2006). The $\mathrm{Pb}_{12}{ }^{2-}$ and $\mathrm{Pb}_{10}{ }^{2-}$ Zintl ions and the $\mathrm{M} @ \mathrm{~Pb}_{12}{ }^{2-}$ and $\mathrm{MPb}_{10}{ }^{2-}$ cluster series where M=Ni,Pd,Pt. J. Am. Chem. Soc., 128, 9178-9186. https://doi.org/10.1021/ja061842m

Fehlner, T. P., \& Halet, J. F. (2007). Molecular Clusters, Cambridge University Press, UK. https://doi.org/10.1017/CBO9780511628887

Housecroft, C. E., \& Sharpe, A. G. (2005). Inorganic Chemistry, $2^{\text {nd }}$ Ed., Pearson, Prentice Hall, Harlow, England

Huang, X., Zhao, J., Chen, Z., \& King, R. B. (2014). Design of Three-shell Icosahedral Matryoshka Clusters A@B12@A20. Scientific Reports, 4, 1-7. 
King, R. B., \& Zhao, J. (2006). The isolable matryoshka nesting doll icosahedral cluster, As@Ni12@As203-, as a superatom: analogy with the jellium cluster $\mathrm{Al}_{13}{ }^{-}$generated in the gas phase by laser vaporization. Chem. Comm., 4204-4205.

Kiremire, E. M. (2015). Beads, Necklaces, Chains and Strings in Capping Carbonyl Clusters. Orient. J. Chem., 31(3), 1243-1261. https://doi.org/10.13005/ojc/310301

Kiremire, E. M. R. (2016a). Classification of Zintl Ion Clusters Using 4n Series Approach. Orient. J. Chem., 32(4), 1731-1738. https://doi.org/10.13005/ojc/320401

Kiremire, E. M. R. (2016b). A Hypothetical Model for the Formation of Transition Metal Carbonyl Clusters Based upon 4n Series Skeletal Numbers. Int. J. Chem., 8(4), 78-110. https://doi.org/10.5539/ijc.v8n4p78

Kiremire, E. M. R. (2016c). The Application of 4N Series Method to Categorize Metalloboranes. Int. J. Chem., 8(3), 62-73. https://doi.org/10.5539/ijc.v8n3p62

Kiremire, E. M. R. (2016d). Clusters of Gold Containing P-Block Elements. Am. J. Chem., 6(5), 126-144.

Kiremire, E. M. R. (2017c). Boranes, Metalloboranes, Transition Metal Carbonyls and Other Cluster Formulas Obey the Law of Skeletal Numbers and Their Valences. Am. J. Chem., 7(4), 113-144.

Kiremire, E. M. R. (2017d). The Golden Series and Clusters of Gold-unique Shapes and Bonding. Int. J. Chem., 9(1), 38-57. https://doi.org/10.5539/ijc.v9n1p38

Kiremire, E. M. R. (2018a). Graph Theory of Chemical Series and Broad Categorization of Clusters. Int. J. Chem., 10(1), 17-80. https://doi.org/10.5539/ijc.v10n1p17

Kiremire, E. M. R. (2018b). Graph Theory of Capping Golden Clusters. Int. J. Chem., 10(1), 87-130. https://doi.org/10.5539/ijc.v10n1p87

Kiremire, E. M. R. (2018c). A Simple Graph Theory of Zintl Ions and other clusters derived from skeletal numbers and their valences. Accepted for publication, Inter. J. Chem.

Kiremire, E. M. R. (2018d). Graph Theory of Chemical Series and Broad Categorization of Clusters. Int. J. Chem., 10(1), 17-80. https://doi.org/10.5539/ijc.v10n1p17

Kiremire, E.M.R. (2017a). The six silent laws of chemical clusters. Am. J. Chem., 7(2), 21-47.

Kiremire, E.M.R. (2017b). The Outstanding Applications of Skeletal Numbers to Chemical Clusters. Int. J. Chem., 9(3), 28-48. https://doi.org/10.5539/ijc.v9n3p28

Konishi, K. (2014). Phosphine-Coordinated Pure-Gold Clusters and Unique Optical Properties /Responses. Structure and Bonding, 161, 49-86. https://doi.org/10.1007/430_2014_143

Langmuir, I. (1921). Types of Valence. Science, 54, 59-67. https://doi.org/10.1126/science.54.1386.59

Lewis, G. N. (1916). The Atom and the Molecules. J. Am. Chem. Soc., 38(4), 762-785. https://doi.org/10.1021/ja02261a002

Mingos, D. M. P. (1984). Gold Cluster Compounds: Are they materials in miniature? Gold Bull., 17(1), 5-12. https://doi.org/10.1007/BF03214670

Moses, M. J., Fettinger, J. C., \& Eichhorn, B. W. (2003). Interpenetrating As20 Fullerine and Ni12 Icosahedra in Onion-Skin: As@ $\mathrm{Ni}_{12} @ \mathrm{As}_{20}{ }^{3-}$. Science, 300, 778-780. https://doi.org/10.1126/science.1082342

Rossi, F., \& Zanello, P. (2011). Electron Reservoir Activity of High-Nuclearity Transition Metal Carbonyl Clusters. Portugaliae Electrochimica Acta, 29(5), 309-327. https://doi.org/10.4152/pea.201105309

Stegmaier, S., \& Fässler, T. F. (2011). A Bronze Matryoshka: The Discrete Intermetalloid Cluster, $\mathrm{Sn} @ \mathrm{Cu} 12 @ \mathrm{Sn} 2012$-in the Ternary phases $\mathrm{A}_{12} \mathrm{Cu}_{12} \mathrm{Sn}_{21} ; \mathrm{A}=(\mathrm{Na}, \mathrm{K})$. J. Am. Chem. Soc., 133, 19758-19768. https://doi.org/10.1021/ja205934p

\section{Copyrights}

Copyright for this article is retained by the author(s), with first publication rights granted to the journal.

This is an open-access article distributed under the terms and conditions of the Creative Commons Attribution license (http://creativecommons.org/licenses/by/4.0/). 